\title{
Species turnover in the Swedish bird fauna 1850-2009 and a forecast for 2050
}

\author{
Artomsättningen i den svenska fågelfaunan 1850-2009 samt en prognos för 2050
}

\author{
FREDRIK HAAS, MORGANE BARBET-MASSIN, MARTIN GREEN, FRÉDÉRIC JIGUET \& ÅKE \\ LINDSTRÖM
}

\begin{abstract}
There is presently great concern about local, regional and global loss of species. We examined those breeding species and subspecies ("species") of birds that either established themselves or went extinct in Sweden in 1850-2009. In this period Sweden got 38 new and lost twelve breeding bird species. The average (and surprisingly steady) rate of colonization was 2.4 species per decade, which was three times higher than the rate of extinction of 0.75 species per decade. We also predict future establishments and extinctions until year 2050, based on Species Distribution Modelling and recent information from neighbouring countries. We find it probable that eleven new species will join the Swedish avifauna until 2050 and possible that another nine species will do so. The predicted rate of probable establishment is 2.9 species per decade. We identified seven species/subspecies to be at risk of extinction by 2050. The future in Sweden for several of these species is probably dependent on the success or failure of ongoing conservation programs. There seems to be no immediate threat of establishment of alien species.

Fredrik Haas, Department of Biology, Biodiversity Unit, Lund University, Ecology Building, S-223 62 Lund, Sweden: E-mail: Fredrik.Haas@biol.lu.se

Morgane Barbet-Massin, Department of Ecology and Evolutionary Biology, Yale University, New Haven, CT 06520, USA, and UMR7204 MNHN-CNRS-UPMC, Centre d'Ecologie et des Sciences de la Conservation, Museum National d'Histoire Naturelle, CP 51, 55 rue Buffon, 75005 Paris, France

Martin Green, Department of Biology, Biodiversity Unit, Lund University, Ecology Building, S-223 62 Lund, Sweden

Frédéric Jiguet, UMR7204 MNHN-CNRS-UPMC, Centre d'Ecologie et des Sciences de la Conservation, Museum National d'Histoire Naturelle, CP 51, 55 rue Buffon, 75005 Paris, France

Ake Lindström, Department of Biology, Biodiversity Unit, Lund University, Ecology Building, S-223 62 Lund, Sweden
\end{abstract}

Received 19 August 2014, Accepted 25 November 2014, Editor: S. Svensson

\section{Introduction}

The number of regularly breeding bird species in Sweden was recently estimated at 252 (Ottosson et al. 2012), which constitutes more than $80 \%$ of the around 300 species that nest in the Nordic countries (Asbirk et al. 1997). It is frequently argued that Sweden's flora and fauna have been impoverished in modern times, but as far as the number of bird species breeding in Sweden is concerned, this is not correct. The number of breeding bird species in Sweden rose between 1850 and 1970 . During this period 27 species became established in Sweden, while nine species were lost (Järvinen \& Ulfstrand 1980). Järvinen \& Ulfstrand (1980) noted that the majority of changes in the avifauna could be explained by anthropogenic effects, such as increased/decreased hunting, changes in land use, and eutrophication. The aim of the present study was to update the analysis of Järvinen \& Ulf- strand (1980) and to predict future establishments and extinctions in Sweden up to 2050.

New types of models (Ecological Niche Models, Species Distribution Models) have demonstrated that even when using a limited number of environmental variables it is possible to predict present species distribution with reasonably high accuracy (Huntley et al. 2007, Swenson 2008, Pigot et al. 2010, Barbet-Massin et al. 2012). These models have also been used to predict future species distributions. Huntley et al. (2007) modelled the present and future breeding distribution of 431 European bird species. Barbet-Massin et al. (2012) compared the modelled present distributions of 409 European bird species with projections of future potential breeding distributions (in 2050), based on present habitat and climate data as well as scenarios for the future. More than $70 \%$ of the species are predicted to reduce their ranges and the number of species 


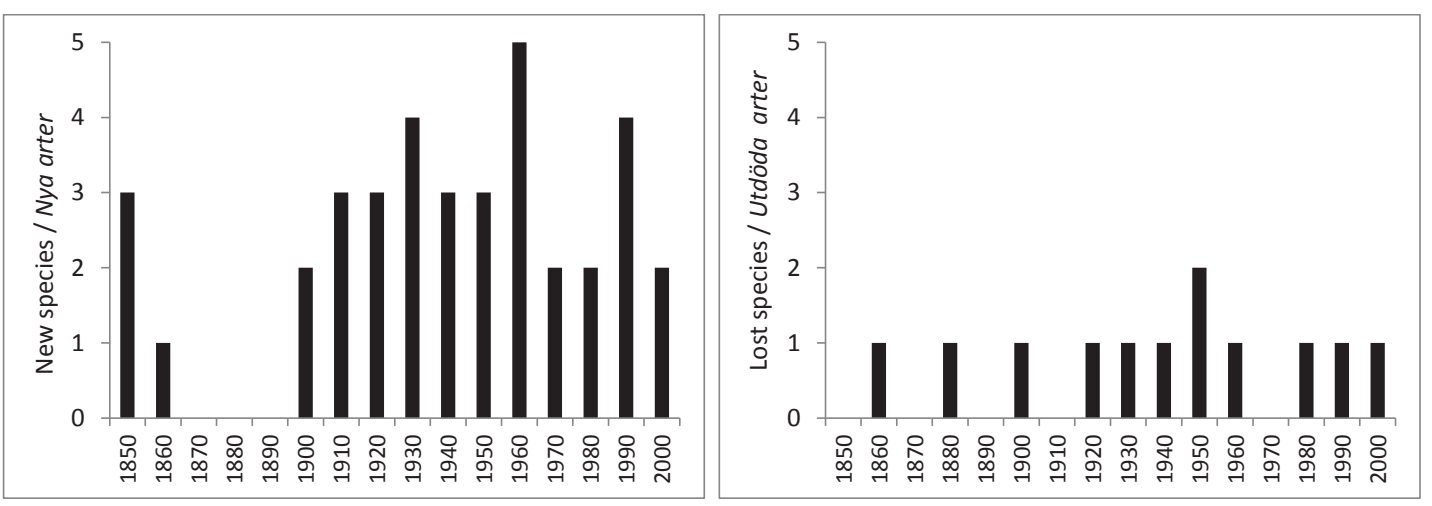

Figur 1. The number of new (left graph) and extinct (right graph) bird species in Sweden per decade. Antal nyetablerade (vänster figur) och utdöda (höger figur) fägelarter i Sverige per decennium.

is predicted to decrease in southern Europe (Barbet-Massin et al. 2012). In contrast, the number of species is predicted to increase in northern Europe. A study centred on the future of species diversity of plants, which also included climate change, showed qualitatively similar results for northern Europe (Thuiller et al. 2005).

The changes predicted seem to be in progress already. In the UK, many species with southern distribution have expanded northwards (Thomas \& Lennon 1999). Jiguet et al. (2010) examined how the population growth of 62 bird species in France, the Netherlands and Sweden has been affected by changes in the average temperature during the nesting season. Within a species range, populations breeding close to their thermal maximum had lower growth rates than populations breeding close to their thermal minimum. One effect of this would be that, in general, species distributions will shift northwards. In Sweden, recent studies have shown that bird communities are gradually changing to include more thermophilic southern species (Lindström et al. 2013) and especially in the north, the number of species at local level increased in parallel to warmer summers (Davey et al. 2013). In addition, Jiguet et al. (2013) found that today's bird trends in Sweden are consistent with the projections of future distribution in the country, as anticipated by Barbet-Massin et al. (2012). The species predicted to expand their distribution range by 2050 are currently increasing in numbers, and vice versa (Jiguet et al. 2013). Another general trend is that habitat generalists tend to have more positive population growth rates in Europe than habitat specialists (Le Viol et al. 2012).

While a fairly steady species turnover occurred already between 1850 and 1970 (Figure 1), the turnover rate may increase in the future as a consequence of global warming. Species with their southern limit in northern Sweden may eventually be lost from the breeding avifauna, while species with their northern boundary south of Sweden may establish themselves. The latter process can be expected to weigh over because species richness in the areas south of Sweden is much greater than that in northern Sweden (Huntley et al. 2007).

We have compiled data on species gains and losses in Sweden in 1970-2009. By combining these results with those presented by Järvinen \& Ulfstrand (1980) we attempt a comprehensive picture of the turnover of bird species between 1850 and 2009. We briefly discuss what characterize the species that have joined or disappeared from the Swedish breeding avifauna. By combining recent modelling of future distributions of birds in Europe (Barbet-Massin et al. 2012) with information about recent changes in the bird fauna in neighbouring countries, we then predict which species may have been gained and lost, respectively, by 2050. Changes in distribution and abundance within Sweden are of course highly related processes, but are not addressed specifically here.

\section{Methods}

\section{Changes in (1850-) 1970-2009}

Data of establishments and extinctions for 1850 1970 were exclusively taken from Järvinen \& Ulfstrand (1980). A few of their interpretations can be discussed, but we refrained from doing so, since changing the interpretation of a few species would not change the general picture. The same uncer- 
tainty also holds for a few of our own interpretations for the period 1970-2009. Details of the new species since 1970 have primarily been extracted from Ottosson et al. (2012). With established species we mean species that nest in Sweden annually, with reasonable certainty. This is of course not easy to determine, since many breeding attempts of rare species most certainly go undetected, and, in addition, to a varying degree between species. The principles that we have used to classify species that belong to the breeding avifauna are the same as those used by Ottosson et al. (2012). For example, Marsh Sandpiper Tringa stagnatilis was found to breed or attempt to breed on a few occasions between 2000 and 2009 (Species Gateway/ Bird 2013). This species is likely to breed in habitats and sites in Sweden visited frequently by birdwatchers, and relatively few breeding attempts are therefore likely to have been missed. Accordingly, it has not been considered as an established breeding species. In contrast, the Red-flanked Bluetail Tarsiger cyanurus, which to our knowledge only has been found nesting once in Sweden (in 1996), we consider belonging to the regularly nesting species. There are several summer records of this species from its preferred habitat, i.e. near-natural state boreal forest in northernmost Sweden, despite that the probability of its detection rate must be regarded as very low.

Quail Coturnix coturnix and Avocet Recurvirostra avocetta are present in both the category "established species 1850-2009" and "extinct species 1850-2009." Järvinen \& Ulfstrand (1980) considered them as extinct, but both species later re-established themselves as breeding birds in Sweden.

To investigate whether there are differences in the degree of habitat specialization among the species that have been lost and become established in Sweden, respectively, we used the species-specific habitat specialization indices established by Le Viol et al. (2012). Low index values indicate that a species is a generalist in terms of habitat use during the breeding season, while high values indicate a habitat specialist restricted to only one or a few habitat types.

\section{Species Distribution Models}

The future potential distributions of European breeding birds (year 2050) were modelled by Barbet-Massin et al. (2012). In short, the distribution of 409 European breeding bird species (BWPi 2006) was digitized and described with a resolution of $0.5^{\circ}$ (about $55 \mathrm{~km}$ in latitudinal direction) across the whole Western Palaearctic. Seabirds were excluded from the analysis. Eight variables (again with resolution $0.5^{\circ}$ ) describing the contemporary climate were retrieved from the Climate Research Unit (http://www.cru.uea.ac.uk/data). Habitat Data (nine habitat types, resolution $0.5^{\circ}$ ), both current and future (2050), came from the IMAGE 2.4 model (MNP 2006). Barbet-Massin et al. 2012 projected the future distributions of all species under climate change based on five general circulation models (GCM; BCM2, ECHAM5, HADCM3, MIROHIC3 2-HI, and MK3) and three different emission scenarios (SRES: A1B, B1, and A2) (IPCC 2007). More details can be found in Barbet-Massin et al. (2012). The predicted future distributions within Sweden are an important part of the present study.

The basic principle when using Species Distribution Models is the projection of a species' environmental niche (climate and/or habitat) on map layers describing the distribution of relevant habitat types (for example, the proportion of coniferous forest in each $0.5^{\circ} \times 0.5^{\circ}$ square) and climate variables (for example average annual temperature per $0.5^{\circ} \times 0.5^{\circ}$ square). One then statistically determines which variables best explain a species' distribution pattern. Barbet-Massin et al. (2012) trained a number of such models by fitting present-day values of habitat and climate on present distributions. When the models were well calibrated the authors could ask the question: given that the species $\mathrm{X}$ occurs in this climate and these habitats, where will it occur in 2050? Following this, predicted distribution maps (SDM50) were produced, where the species' most likely distributions in 2050 were illustrated by differently coloured squares $(55 \times 55 \mathrm{~km})$. The colours indicate the likelihood of an area being suitable for a given species. It should be emphasized that this approach presupposes niche conservatism. As a check of accuracy, models were also used to produce maps of contemporary distribution (SDM00). For species with very specific habitat requirements the models did not do very well, due to the low geographical resolution. As a consequence, the models generate more uncertain results for species strongly associated with water, such as exclusively coastal species.

Based on the SDM50 we directed our attention to two categories of species: 1) New breeding species: those who currently do not breed in Sweden, but are likely to occur in Sweden by 2050 according to SDM50, 2) Extinctions: those species who breed in Sweden today, but according to SDM50 have zero percent probability to exist in 2050 . 
For each of the distribution maps which suggested the establishment in Sweden of a new breeding species, we counted the number of squares that showed a future occurrence with a probability of $>0.5$, the number of squares that showed a future occurrence with a probability $>0$, and also noted the probability value for the square with the highest probability of establishment.

\section{Establishment in 2010-2050}

The final decision of whether a species is likely to breed in Sweden in 2050 was based on two main sources of information: 1) the modelling of Barbet-Massin et al. (2012) as described above, and 2) information about recent distribution and population dynamics in the neighbouring countries to Sweden (Table 1). Model forecasts are attractive to use because they are basically free from our own preconceptions. On the other hand they are not om- nipotent and will sometimes give erroneous predictions (even for present and known distribution, see below). For our final predictions we have therefore balanced model outcomes with other available information.

The main focus is on a number of species that were assessed as probable or possible breeders in Sweden in 2050. We also discuss some additional species where it is conceivable that they will become established until 2050, but where there is a much higher uncertainty.

To be evaluated as a probable newcomer, a given species should have at least four squares with a probability of future occurrence of $>0.5$ in SDM50. There must also be other data in support, such as the species expanding in nearby countries. Included are also species that are not predicted to occur in Sweden according to the criteria above, but where other circumstances may point at a probable establishment, such as strong recent range expansion in

Table 1. Population trend data from some neighbouring countries used to evaluate the likelihood of future establishment in Sweden for bird species that do not breed regularly (see Table 4 and 5). The column Trend shows how the trends are described in this report. More details are given in note \#3.

Kringliggande länders och regioners trenddata som utnyttjats som jämförelse till de modellerade prediktionerna av framtida förekomst (se tabell 4 och 5). Under Trend anges hur trenderna redovisas $i$ denna rapport. Närmare förklaring ges i not 3 .

\begin{tabular}{|c|c|c|c|c|}
\hline Country Land & Code Kod & Period & Trend $^{3}$ & Source Källa \\
\hline Germany Tyskland & $\mathrm{D}$ & 1980-2005 & $++,+, 0,-,--$ & $\begin{array}{l}\text { Südbeck m.fl. } \\
\text { (2007) }\end{array}$ \\
\hline $\begin{array}{l}\text { Netherlands } \\
\text { Nederländerna }\end{array}$ & NL & 2002-2011 & $++,+, 0,-,--$ & $\begin{array}{l}\text { Netwerk Ecologische } \\
\text { Monitoring } \\
\text { (2012) }\end{array}$ \\
\hline $\begin{array}{l}\text { Belgium Belgien } \\
\text { Vallonien }\end{array}$ & BEVal & 1990-2009 & $++,+, 0,-,--$ & $\begin{array}{l}\text { Paquet m.fl. } \\
(2010)\end{array}$ \\
\hline Poland Polen & PL & 2000-2013 & $++,+, 0,-,--$ & $\begin{array}{l}\text { Chodkiewicz m.fl. } \\
\text { (2013) }\end{array}$ \\
\hline UK Storbritannien & GB & Varying Varierande & $++,+, 0,-,--$ & Baillie m.fl. (2013) \\
\hline France Frankrike & FR & $1990-2010$ & $\begin{array}{l}\text { Numerical/ } \\
\text { Siffervärde }\end{array}$ & $\begin{array}{l}\text { Jiguet } \\
\text { (unpublished data) }^{2}\end{array}$ \\
\hline Europe Europa & EU & Varying Varierande ${ }^{2}$ & Text & $\begin{array}{l}\text { BirdLife } \\
\text { International (2013) }\end{array}$ \\
\hline
\end{tabular}

${ }^{1}$ The start year varies between species, or is not given, but the last year is always 2011. Startåret varierar mellan arter och/eller framgår inte, men slutåret är konsekvent 2011.

${ }^{2}$ Time span not given but the data are updated continuously. Tidsspannet framgår inte, men uppgifterna uppdateras kontinuerligt.

${ }^{3}$ The symbols,,,+++--- indicate statistically significant trends: $++=$ strong increase, $+=$ moderate increase, moderate decline, $--=$ strong decline, $0=$ stable population. The actual strength of moderate and strong trends varies between studies. The European trends are given in words.

Symbolerna,,,+++--- indikerar statistiskt säkerställda trender: $++=$ kraftig ökning, $+=$ moderat ökning, $--=$ kraftig minskning, - moderat minskning, $0=$ stabil population. Vad som anses vara en moderat respektive kraftig trend varierar något mellan studierna. De franska data redovisas i form av lutningskoefficienten för respektive arts trend, men utan något spridningsmått. Det sammanvägda europaindexet anges, liksom det görs $i$ källan, $i$ textform. 
Table 2. Species that established themselves as breeders in Sweden 1850-2009. The information from 18501969 is from Järvinen \& Ulfstrand (1980). Data on later establishments are from Ottosson et al. (2012), as is information about population sizes, shown for species established from 1970 onwards. For the latter species we also show from which direction the colonization most probably took place. Habitat preference is also given (from Solonen 1994; $\mathrm{A}=$ Coastal, $\mathrm{C}=$ Farmland, $\mathrm{F}=$ Forest, $\mathrm{O}=$ Bushes and open ground, $\mathrm{S}=$ Beeches $(*=$ not included in Solonen 1994). HSI is the habitat specialization index (from LeViol et al. 2012). The higher values, the more specialized a species is.

Arter som etablerat sig i den svenska häckfågelfaunan under perioden 1850-2009. Uppgifterna för 1850-1969 är hämtade från Järvinen och Ulfstrand (1980). Senare etableringar är hämtade från Ottosson m.fl. (2012), liksom den nuvarande populationsstorleken (antal par), vilket visas för arter etablerade från 1970 och framåt. För det senare tidsspannet visas även rekryteringsområde (från vilket vädersträck etableringen troligast skett) och häckningsbiotop (efter Solonen 1994); A=arkipelag, $C=$ kulturmark, $F=$ skog, $O=$ busk- och öppenmark, $S=$ stränder. ${ }^{*}=$ ej med $i$ Solonen 1994. Habitatsspecialiseringsindex (HSI) visas för samtliga arter (hämtade från Le Viol m.fl., 2012). Ju högre värde desto mer specialiserad är arten.

\begin{tabular}{|c|c|c|c|c|c|}
\hline $\begin{array}{l}\text { Species } \\
\text { Art }\end{array}$ & $\begin{array}{c}\text { Decade of } \\
\text { establishment } \\
\text { Decennium } \\
\text { för etablering }\end{array}$ & $\begin{array}{r}\text { No. of } \\
\text { pairs } \\
\text { Antal par }\end{array}$ & $\begin{array}{l}\text { Colonization } \\
\text { from } \\
\text { Rekryterings- } \\
\text { område }\end{array}$ & $\begin{array}{l}\text { Habitat } \\
\text { Biotop }\end{array}$ & HSI \\
\hline Phalacrocorax aristotelis & 2000 & 35 & NW/NV & A & 6.93 \\
\hline Saxicola torquata & 2000 & 4 & $\mathrm{SW} / \mathrm{SV}$ & $\mathrm{O}$ & 2.82 \\
\hline Coturnix coturnix & 1990 & 1000 & $\mathrm{~S}$ & $\mathrm{C}$ & 4.22 \\
\hline Locustella luscinioides & 1990 & 30 & SSE/SSO & $\mathrm{S}$ & 6.89 \\
\hline Regulus ignicapillus & 1990 & 100 & SW/SV & $\mathrm{F}$ & 3.26 \\
\hline Tarsiger cyanurus & 1990 & 10 & $\mathrm{E} / \mathrm{O}$ & $\mathrm{F}$ & 9.27 \\
\hline Locustella fluviatilis & 1980 & 150 & $\mathrm{SE} / \mathrm{SO}$ & $\mathrm{O}$ & 4.17 \\
\hline Acrocephalus dumetorum & 1980 & 55 & $\mathrm{E} / \mathrm{O}$ & $\mathrm{O}$ & 4.61 \\
\hline Carduelis flammea cabaret & 1970 & $>1000$ & $\mathrm{SW} / \mathrm{SV}$ & $\mathrm{F}^{*}$ & \\
\hline Branta leucopsis & 1970 & 4900 & $\mathrm{NE} / \mathrm{NO}$ & $\mathrm{A}$ & 2.88 \\
\hline Milvus migrans & 1960 & & & & 2.57 \\
\hline Rissa tridactyla & 1960 & & & & 6.71 \\
\hline Remiz pendulinus & 1960 & & & & 6.89 \\
\hline Panurus biarmicus & 1960 & & & & 6.89 \\
\hline Phylloscopus trochiloides & 1960 & & & & 4.72 \\
\hline Phylloscopus c. collybita & 1960 & & & & 2.89 \\
\hline Streptopelia decaocto & 1950 & & & & 2.69 \\
\hline Phylloscopus borealis & 1950 & & & & 4.65 \\
\hline Emberiza pusilla & 1950 & & & & 6.32 \\
\hline Phalacrocorax carbo & 1940 & & & & 3.63 \\
\hline Ficedula parva & 1940 & & & & 5.33 \\
\hline Serinus serinus & 1940 & & & & 2.42 \\
\hline Branta canadensis & 1930 & & & & \\
\hline Circus pygargus & 1930 & & & & 2.79 \\
\hline Oriolus oriolus & 1930 & & & & 2.51 \\
\hline Carpodacus erythrinus & 1930 & & & & 2.44 \\
\hline Podiceps nigricollis & 1920 & & & & 6.89 \\
\hline Recurvirostra avosetta & 1920 & & & & 3.01 \\
\hline Locustella naevia & 1920 & & & & 3.91 \\
\hline Sterna sandvicensis & 1910 & & & & 3.64 \\
\hline Acrocephalus arundinaceus & 1910 & & & & 4.91 \\
\hline Motacilla cinerea & 1910 & & & & 9.85 \\
\hline Alcedo atthis & 1900 & & & & 5.69 \\
\hline Phoenicurus ochruros & 1900 & & & & 3.40 \\
\hline Tyto alba & 1860 & & & & 2.67 \\
\hline Aythya ferina & 1850 & & & & 3.76 \\
\hline Gallinula chloropus & 1850 & & & & 4.91 \\
\hline Galerida cristata & 1850 & & & & 2.72 \\
\hline
\end{tabular}


nearby areas.

For some species SDM00 show that current conditions in Sweden are very suitable, but the birds are clearly not present, such as Snow Finch Montifringilla nivalis and Alpine Accentor Prunella collaris. These two mainly sedentary species breed in the mountains of southern Europe and the likelihood of establishment in Sweden in the near future must be considered extremely low. For such species the predicted distribution in Sweden (SDM50) was handled with particular care.

To be a candidate for possible establishment by 2050 , a given species should exhibit one or more squares with a probability of $>0.5$ in SDM50. SDM00 should show no presence in areas that are clearly outside the species' actual distribution. Other data should not speak against an establishment.

\section{Extinction}

For a species to be considered as likely to go extinct, SDM50 should predict no future distribution for a species present today in reality and according to SDM00. Nor should other information speak against extinction.

\section{Result and discussion}

New species and extinctions 1970-2009

Järvinen \& Ulfstrand (1980) noted that between 1850 and 1970, 27 new species established themselves (Table 2). In addition, one subspecies, the southern Chiffchaff Phylloscopus c. collybita established itself in the 1960s (Bengtsson \& Green 2013). During the same period nine species went extinct. Below we continue the work of Järvinen and Ulfstrand and present the results for the period 1970-2009.

In 1970-2009, nine species and one subspecies (Lesser Redpoll Carduelis flammea cabaret) established themselves in Sweden (Table 2). This is an establishment rate of 2.5 species per decade, which is very similar to the 2.3 (based on 27 species and one subspecies) species per decade which were added between 1850 and 1969. Accordingly, the rate of establishment of new species in Sweden has been fairly constant since 1850 (Figure 1). In addition to the ten above mentioned species and subspecies, there is now a small population of White Stork Ciconia ciconia in southern Sweden. This reestablishment of a previously extinct species is the result of re-introduction project starting in 1989.
We have therefore chosen to exclude it from the calculations above.

There is no clear common denominator for those species that have established themselves over the past 40 years (Table 2). The species have originated predominantly from areas south of Sweden, but almost all compass directions are represented. For example, the Shag Phalacrocorax aristotelis most certainly came in from Norway (NW) and the Barnacle Goose Branta leucopsis from the Russian Arctic (NE). Three of the newly established species breed in woodland and three species breed in shrubland. Of the three shrubland species, the Stonechat Saxicola rubicola prefers more open habitat, whereas the River Warbler Locustella fluviatilis and Blyth's Reed Warbler Acrocephalus dumetorum prefer denser bushland. The latter two species are of eastern origin and their expansion may at least partly have benefited from the spread of bushland on abandoned farmland. The same may hold for the Booted Warbler Iduna caligata, a probable future breeder in Sweden (for more details, see below).

Between 1970 and 2009, three species disappeared from the Swedish breeding avifauna: Middle Spotted Woodpecker Dendrocopus medius (Pettersson 1985), Crested Lark Galerida cristata and Kentish Plover Charadrius alexandrinus (Swedish Species Information Centre 2011a). The rate of extinction was 0.75 species per decade in 1970-2009, as well as in 1850-1969 (Table 3). The extinction rate has thus been fairly constant over time, although it has varied between decades (Figure 2).

Both Kentish Plover and Crested Lark had very small populations in Sweden already during the past 50-60 years before extinction (Swedish Species Information Centre 2011a, 2012a). The two species have also declined over much of Europe (BirdLife International 2013). For example, the Crested Lark population decreased in Denmark by more than $80 \%$ between 1990 and 2000. In 2011, the Danish population consisted of only two pairs (DOF 2013). During the same time period also the Kentish Plover population decreased by more than $80 \%$ in Denmark. The extinction in Sweden of these two species therefore coincided with geographically large-scale reductions and sharp declines of populations in adjacent areas. The background to the extinction of the Middle Spotted Woodpecker is addressed later in this report under "Establishment probable".

Between 1850 and 1969 the ratio of new to extinct species was 3.1 (Järvinen \& Ulfstrand 1980). 
Table 3. Species that went extinct in Sweden 1850-2009. The information for 1850-1969 is from Järvinen \& Ulfstrand 1980. For the species lost between 1970 and 2009 is also shown the preferred breeding habitat according to Solonen 1994; $\mathrm{F}=$ Forest, $\mathrm{O}=$ Bushes and open ground, $\mathrm{S}=$ Beeches $(*=$ not included in Solonen 1994). HSI is the habitat specialization index (from LeViol et al. 2012) The higher values, the more specialized a species is.

Arter som förlorats från den svenska häckfågelfaunan under perioden 1850-2009. Uppgifterna för 1850-1969 är hämtade från Järvinen och Ulfstrand (1980). För de arter som förlorats mellan 1970 och 2009 visas huvudsakligt häckningshabitat (efter Solonen 1994); $F=$ skog, $O=$ busk- och öppenmark, $S=$ stränder. * $=e j$ med $i$ Solonen (1994). Habitatsspecialiseringsindex (HSI) visas för samtliga arter (hämtade från Le Viol m.fl., 2012). Ju högre värde desto mer specialiserad är arten.

\begin{tabular}{lcccl}
\hline Species & $\begin{array}{c}\text { Decade of } \\
\text { extinction } \\
\text { Decennium } \\
\text { för } \text { utdöende }\end{array}$ & Biotop & HSI & Källa \\
\hline Charadrius alexandrinus & 2000 & $\mathrm{~S}$ & 2.95 & $\begin{array}{l}\text { Swedish Species } \\
\text { Information Centre (2010d) } \\
\text { Swedish Species }\end{array}$ \\
Galerida cristata & 1990 & $\mathrm{O}$ & 2.72 & $\begin{array}{l}\text { Source } \\
\text { Information Centre (2010e) }\end{array}$ \\
Dendrocopos medius & 1980 & $\mathrm{~F} *$ & 4.36 & Holmbring \& Petterson (1983) \\
Coracias garrulus & 1960 & & 2.62 & \\
Fratercula arctica & 1950 & & 4.79 & \\
Ciconia ciconia & 1950 & & 3.06 & \\
Coturnix coturnix & 1940 & & 4.22 & \\
Ciconia nigra & 1930 & & 3.11 & \\
Upupa epops & 1920 & & 2.56 & \\
Phalacrocorax carbo & 1900 & & 3.63 & \\
Recurvirostra avosetta & 1880 & & 3.01 & \\
Otis tarda & 1860 & & 5.45 & \\
\hline
\end{tabular}

For the period 1970-2009, the ratio was 3.3. Järvinen \& Ulfstrand (1980) suggested that the majority of changes in the avifauna up to 1970 could be explained by anthropogenic effects, such as increased/decreased hunting, changes in land use, and eutrophication. It is difficult to say to what extent human activities have contributed directly or indirectly to the continued colonization of Sweden in 1970-2009, but it is clear that, whatever the anthropogenic effect, the number of breeding species in Sweden has continued to rise. A contributing factor is most certainly a warmer climate, especially in recent decades, and it may become even more important in the future. Both Huntley et al. (2007) and Barbet-Massin et al. (2012) have indeed predicted that the number of bird species will increase in northern Europe in the near future.

It should not be forgotten that in addition to establishments and extinctions there have been some dramatic changes in the number of individuals of different species in the Swedish avifauna, at least partly caused by anthropogenic activities and climate change. However, these changes and their causes are outside the scope of this report (more information can be found in Ottvall et al. 2009, Ottosson et al. 2012, Lindström \& Green 2013, Jiguet et al. 2013).

On a European scale, it has been shown that habitat generalists are overrepresented among the species exhibiting population growth and that specialist more often are declining in numbers (Le Viol et al. 2012). We tested whether this pattern holds also for new and extinct species in Sweden between 1850 and 2010. However, a comparison of the habitat specialization index (HSI) of the two groups shows the opposite (Tables 2 and 3). The mean HSI for the species that were lost was 3.54 $(\mathrm{SD}=0.95)$, while for the new species it was 4.60 $(\mathrm{SD}=1.97)$. The difference is significant (Welch's $\mathrm{t}$-test $=2.45, \mathrm{df}=40, \mathrm{p}<0.05$ ). This means that according to the HSI, the species lost are more general in their habitat choices than those established. However, this should be interpreted with caution, especially since the absolute difference in HSI between the two groups is quite small. The habitat classification basis for the index is also relatively coarse and does not take into account that different species can use different microhabitats within a given environment. With that said, with respect to local extinctions and establishment, it is clearly not as simple as saying that habitat specialists are the losers and generalists the winners. 

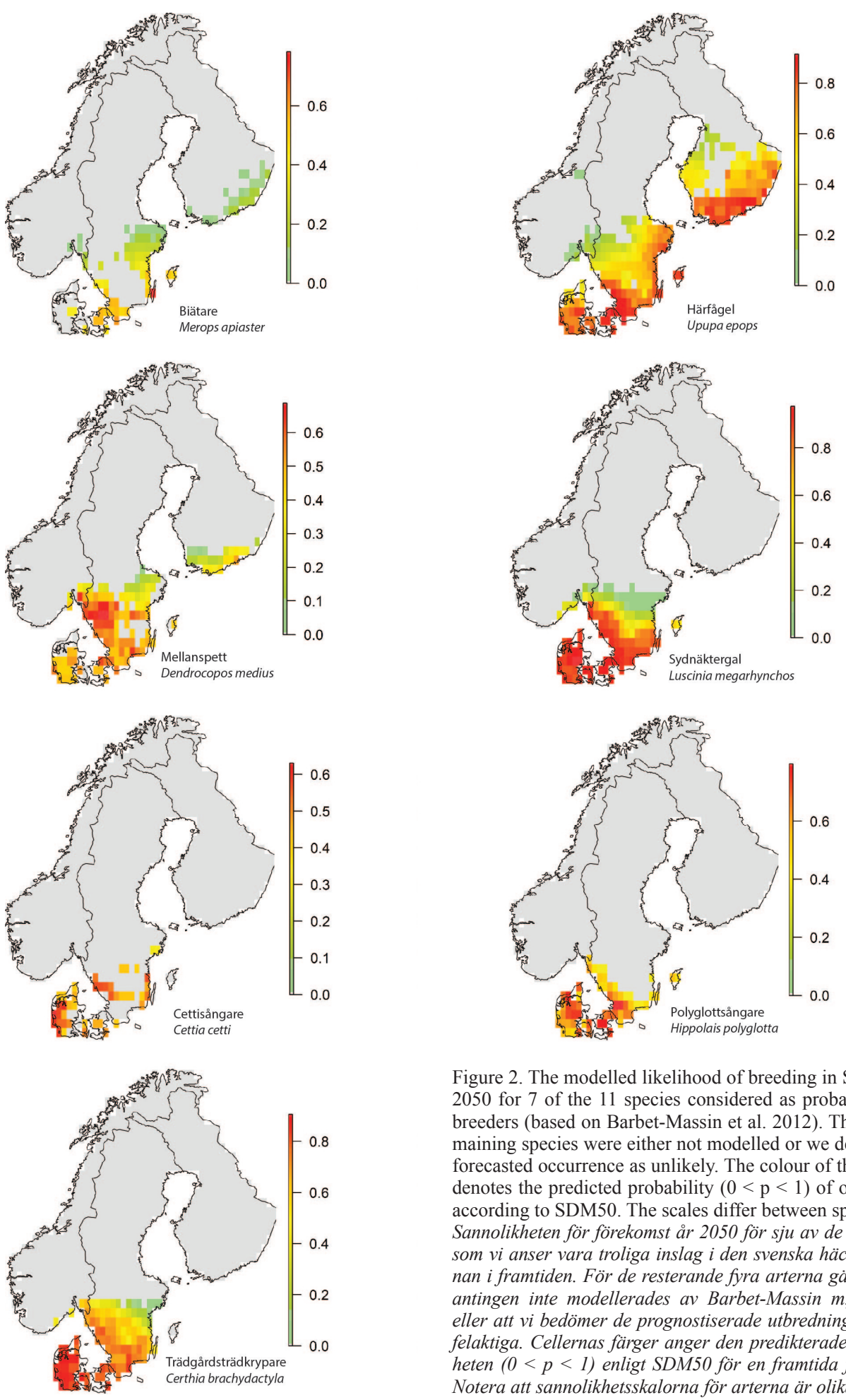

Figure 2. The modelled likelihood of breeding in Sweden in 2050 for 7 of the 11 species considered as probable future breeders (based on Barbet-Massin et al. 2012). The four remaining species were either not modelled or we deemed the forecasted occurrence as unlikely. The colour of the squares denotes the predicted probability $(0<\mathrm{p}<1)$ of occurrence according to SDM50. The scales differ between species.

Sannolikheten för förekomst år 2050 för sju av de elva arter som vi anser vara troliga inslag $i$ den svenska häckfågelfaunan i framtiden. För de resterande fyra arterna gäller att de antingen inte modellerades av Barbet-Massin m.fl. (2012) eller att vi bedömer de prognostiserade utbredningarna som felaktiga. Cellernas färger anger den predikterade sannolikheten $(0<p<1)$ enligt SDM50 för en framtida förekomst. Notera att sannolikhetsskalorna för arterna är olika. Utbredningskartorna är baserade på Barbet-Massin m.fl. (2012). 
In Denmark, 149 bird species were reported as breeding in year 1800. In 1995, the year in which the highest number of species is considered to have bred in Denmark, 178 species bred (Romdal et al. 2013). In 2012, the number of breeding species had decreased to 173 (Romdal et al. 2013). Ottosson et al. (2012) estimated that around 2010, 252 species bred in Sweden. There is no exact figure for Sweden in 1850 , but if we take 252 minus the net number of species that established between 1850 and 2009, 227 species should have bred in 1850 . This means that the number of species in Denmark increased by 1.5 species per decade between 1800 and 1995, while the increase in Sweden was on average 1.6 species per decade between 1850 and 2010 . The similarity in rate is striking given that the countries vary widely in area and habitat. The explanation may partly be that the two neighbouring countries in many cases are affected by the same waves of colonisation.

\section{Establishments 2010-2050}

We consider it probable that the Swedish breeding bird fauna will host eleven new species by 2050 (Table 4), with another nine species as possible newcomers (Table 5). These two categories of species are given specific comments below. If we only include the group of probable colonizers this would mean an establishment rate of 2.9 species per decade. The corresponding rate when including also possible colonizers is 5.3 species per decade. In addition to the species treated under probable or possible establishment, there are another nine species worth mentioning as future breeding birds in Sweden, although the signs for colonization are much weaker than for the first two groups. These ten conceivable species are discussed briefly at the end of this section.

It should be kept in mind when reading the next section that SDM50 make the assumption of niche conservatism, and that some species expanding since 50 years like the Mediterranean Gull or the Great White Egret might be expanding also their niches and so their potential distribution, a phenomenon not captured by SDM.

\section{Probable establishments 2010-2050}

\section{Little Egret Egretta garzetta}

The Little Egret is a wetland bird which presently has its closest breeding population to Sweden in the UK, where it first bred in 1996 (Robinson 2005), and in the Netherlands, where it became es- tablished in the mid-1990s (Netwerk Ecologische Monitoring 2012). In both countries the species has expanded considerably since then. In Flanders, Belgium it has increased substantially between 2000 and 2007 (Vermeersch \& Anselin 2009). Between 1990 and 2007, the Western European population increased by $7.9 \%$ annually, while the Central and Eastern European populations were considered stable from 1988 to 1998 (Wetlands International 2012).

Given that the species expands northwards in Western Europe, we consider it likely that it before 2050 will be included in the Swedish fauna. This is despite the fact that the SDM50 does not predict any breeding distribution in Sweden. Also in Denmark it is predicted as a future breeding bird (DOF 2013).

\section{Great White Egret Casmerodius albus}

The Great White Egret is another wetland species for which SDM50 does not predict any Swedish breeding population (Table 4), but where we for other reasons find a future establishment as highly likely. The species has expanded dramatically in the western and northern part of the European distribution area and now breeds closest to Sweden in Poland and the Baltic states (Lawicki 2014). Over the past 20 years, it has started to breed in no less than 13 European countries (Ławicki 2014). Wetlands International (2012) estimated the annual population growth rate in Europe at $3.9 \%$ between 1989 and 2006. In 2002-2012, the number of observations per year in Sweden increased steadily from 15 to 140 (Species Gateway/Bird 2013). In addition, in 2012 the first breeding in Sweden was confirmed on the Baltic island of Gotland (Strid \& Eriksson 2013)). Also in Denmark it is forecasted as a future breeding bird (DOF 2013).

\section{Mediterranean Gull Larus melanocephalus}

The Mediterranean Gull nests in shallow lakes and coastal areas (Cramp 1998). It has expanded to the northwest from southeast Europe since the mid-1950s. It nested for the first time in the UK in 1968. The current British population is estimated to 600-700 pairs (JNCC 2013). In Denmark, the species has been a regular breeder since 1998, and in 2011 the Danish population was estimated at 11-14 pairs (DOF 2013). The species has bred in Sweden at least twice: in 2010 (Blekinge) and 2013 (Halland), on each occasion it was a single pair (Species Gateway/Bird 2013). In addition to that, it has hybridized with black-headed gull Chroicocephalus ridibundus a few times. 
Table 4. Species that probably will establish themselves as breeders in Sweden before 2050. "Max p" is the highest probability of occurrence in a cell according to SDM50. "Cells $>0.5$ " is the number of cells with a probability higher than 0.5 , and "Cells $>0$ " is the number of cells with predicted occurrence, all according to SDM50. Population trend data for a number of countries is also shown (see Table 1 for country codes and more detailed information).

Arter som troligen kommer att etablera sig i Sverige fram till 2050. "Max p" är det högsta sannolikhetsvärdet för förekomst för en cell enligt SDM50, "Cells > 0.5" är antalet celler som med en sannolikhet överstigande 0.5 förutspår förekomst enligt SDM50, "Cells > 0" är antalet celler som med en sannolikhet överstigande 0.0 förutspår förekomst enligt SDM50. Trenddata för ett antal länder och regioner visas också (se Tabell 1 för land-/ regionsförkortning, tidsspann för trenderna och symbolik).

\begin{tabular}{|c|c|c|c|c|c|c|c|c|c|c|}
\hline Species $A r t$ & $\begin{array}{c}\operatorname{Max} \\
\mathrm{p}\end{array}$ & $\begin{array}{l}\text { Cells } \\
>0.5\end{array}$ & $\begin{array}{r}\text { Cells } \\
>0 \\
\end{array}$ & D & NL & BEVa1 & PL & GB & FR & EU \\
\hline $\begin{array}{l}\text { Little Egret } \\
\text { Egretta garzetta }\end{array}$ & & & & 0 & + & & & & 0.048 & $\begin{array}{l}\text { Increasing } \\
\text { Ökande }\end{array}$ \\
\hline $\begin{array}{l}\text { Great White Egret } \\
\text { Casmerodius albus }\end{array}$ & & & & & ++ & & & & 0.324 & ? \\
\hline $\begin{array}{l}\text { Mediterranean Gull Larus } \\
\text { melanocephalus }\end{array}$ & & & & + & ++ & & + & & 0.192 & $\begin{array}{l}\text { Stable } \\
\text { Stabil }\end{array}$ \\
\hline $\begin{array}{l}\text { European Bee-eater } \\
\text { Merops apiaster }\end{array}$ & 0.8 & 11 & 51 & + & & & & & 0.067 & ? \\
\hline $\begin{array}{l}\text { Hoopoe } \\
\text { Upupa epops }\end{array}$ & 0.85 & 77 & 110 & 0 & & & + & & 0.059 & $\begin{array}{l}\text { Declining } \\
\text { Minskande }\end{array}$ \\
\hline $\begin{array}{l}\text { Middle Spotted Woodpecker } \\
\text { Dendrocopos medius }\end{array}$ & 0.7 & 56 & 84 & + & ++ & + & + & & 0.110 & $\begin{array}{l}\text { Moderate } \\
\text { increase } \\
\text { Måttlig ökning }\end{array}$ \\
\hline $\begin{array}{l}\text { Nightingale } \\
\text { Luscinia megarhynchos }\end{array}$ & 0.9 & 71 & 104 & 0 & 0 & + & + & - & $\overline{-}$ & $\begin{array}{l}\text { Moderate } \\
\text { increase } \\
\text { Måttlig ökning }\end{array}$ \\
\hline $\begin{array}{l}\text { Cetti's Warbler } \\
\text { Cettia cetti }\end{array}$ & 0.55 & 8 & 21 & & ++ & & & + & & $\begin{array}{l}\text { Strong } \\
\text { increase } \\
\text { Stark ökning }\end{array}$ \\
\hline $\begin{array}{l}\text { Booted Warbler } \\
\text { Iduna caligata }\end{array}$ & & & & & & & & & & $\begin{array}{l}\text { Increasing } \\
\text { Ökande }\end{array}$ \\
\hline $\begin{array}{l}\text { Melodious Warbler } \\
\text { Hippolais polyglotta }\end{array}$ & 0.8 & 18 & 33 & + & & + & & & & Stable Stabil \\
\hline $\begin{array}{l}\text { Short-toed Treecreeper } \\
\text { Certhia brachydactyla }\end{array}$ & 0.85 & 60 & 82 & 0 & + & 0 & - & 0 & & $\begin{array}{l}\text { Moderate } \\
\text { decline } \\
\text { Måttlig } \\
\text { minskning }\end{array}$ \\
\hline
\end{tabular}

Again the SDM50 does not include this wetland species as a future breeder in Sweden, but considering its rapid expansion to the northwest, it is probable that it will establish itself as a breeding bird in Sweden fairly soon.

Middle Spotted Woodpecker Dendrocopos medius The Middle Spotted Woodpecker nested in Sweden until 1982 (Holmbring \& Pettersson 1983, Pettersson 1985). The last occurrence was in oak woodlands in Östergötland (southeast central Sweden). However, the SDM50 predicts a widespread occurrence in the southern half of Sweden (Figure 2). In addition, the species has a positive population growth across Europe (Table 4).

This is a deciduous forest specialist traditionally preferring older oak stands (Kosiński \& Winiecki 2005, Müller et al. 2009). The absence of sufficiently large areas of suitable breeding habitat has been identified as the main cause of the species' disappearance from Sweden (Holmbring \& Pettersson 1983). Interestingly, a study in Belgium showed that the population increase found there was not primarily explained by the presence of old oak, but the availability of old trees of other broadleaved species (Colmant 2006).

The critical aspect of a re-establishment in Sweden is whether Sweden has enough of the habitats required by the Middle Spotted Woodpeckers. The potential dispersal barrier of the Baltic Sea is another potentially hindering factor. The species is, however, encountered twice in 
Table 5. Species that possibly will establish themselves as breeders in Sweden before 2050. "Max p" is the highest probability of occurrence in a cell according to SDM50. "Cells $>0.5$ " is the number of cells with a probability higher than 0.5 , and "Cells $>0$ " is the number of cells with predicted occurrence, all according to SDM50. Population trend data for a number of countries is also shown (see Table 1 for country codes and more detailed information).

Arter som möjligen kommer att etablera sig fram till 2050. Max $p=$ det högsta sannolikhetsvärdet för förekomst för en cell enligt SDM50, Cells > 0.5 = antalet celler som med en sannolikhet överstigande 0.5 förutspår förekomst enligt SDM50, Cells $>0$ = antalet celler som med en sannolikhet överstigande 0.0 förutspår förekomst enligt SDM50 och trenddata för ett antal länder och regioner (se tabell 1 för land-/regionsförkortning, tidsspann för trenderna och symbolik).

\begin{tabular}{|c|c|c|c|c|c|c|c|c|c|}
\hline Species $A r t$ & $\operatorname{Max} p$ & $\begin{array}{l}\text { Cells } \\
>0.5\end{array}$ & $\begin{array}{r}\text { Cells } \\
>0\end{array}$ & D & NL & PL & GB & FR & EU \\
\hline $\begin{array}{l}\text { Little Bittern } \\
\text { Ixobrychus minutus }\end{array}$ & 0.7 & 52 & 62 & -- & + & & & 0.067 & $\begin{array}{l}\text { Declining } \\
\text { Minskande }\end{array}$ \\
\hline $\begin{array}{l}\text { Night heron } \\
\text { Nycticorax nycticorax }\end{array}$ & 0.5 & 1 & 3 & -- & + & + & & -0.002 & $\begin{array}{l}\text { Declining } \\
\text { Minskande }\end{array}$ \\
\hline $\begin{array}{l}\text { Purple Heron } \\
\text { Ardea purpurea }\end{array}$ & 0.5 & 2 & 12 & + & + & & & 0.034 & $\begin{array}{l}\text { Declining } \\
\text { Minskande }\end{array}$ \\
\hline $\begin{array}{l}\text { Black Stork } \\
\text { Ciconia nigra }\end{array}$ & 0.6 & 18 & 69 & + & & $?$ & & 0.039 & ? \\
\hline $\begin{array}{l}\text { Spoonbill } \\
\text { Platalea leucorodia }\end{array}$ & & & & + & + & & & 0.181 & $?$ \\
\hline $\begin{array}{l}\text { Short-toed Eagle } \\
\text { Circaetus gallicus }\end{array}$ & 0.65 & 2 & 75 & & & & & 0.080 & Stable Stabil \\
\hline $\begin{array}{l}\text { Lesser Spotted Eagle } \\
\text { Aquila pomarina }\end{array}$ & 0.5 & 2 & 41 & 0 & & 0 & & & ? \\
\hline $\begin{array}{l}\text { Little Owl } \\
\text { Athene noctua }\end{array}$ & 0.9 & 76 & 105 & 0 & - & & -- & 0.031 & Stable Stabi \\
\hline $\begin{array}{l}\text { Citrine Wagtail } \\
\text { Motacilla citreola }\end{array}$ & & & & & & & & & $\begin{array}{l}\text { Increase } \\
\text { Okande }\end{array}$ \\
\hline
\end{tabular}

southernmost Sweden, in 1989 and 1994 (Cederroth 1996), respectively. These birds had most probably crossed Öresund or the southern Baltic by its own efforts.

\section{European Bee-eater Merops apiaster}

The Bee-eater occurs in open or sparsely wooded areas (Cramp 1998). It is mainly distributed in the southern half of Europe, but also occurs in isolated populations north of this (Hagemeijer \& Blair 1997). The species is increasing in Germany (Table 4) and it is also reported as increasing in Denmark, where it is on the verge of being an established breeding bird (DOF 2013). The Bee-eater has been found nesting on six occasions in Sweden until the late 1990s, with the first nesting record from 1976 (SOF 2002). SDM50 predicts a relatively limited presence in southern Sweden (Fig. 2).

\section{Hoopoe Upupa epops}

The Hoopoe nests over large parts of Europe and has the closest breeding population in Poland and the Baltic states (Hagemeijer \& Blair 1997). It is mainly found near pasture and farmland (Cramp 1998). From 1970 until the mid-1990s it was an almost annual breeding bird in Sweden, with most records from the island of Öland. It is now considered nationally extinct (Swedish Species Information Centre 2011b). The large Polish population of $10000-15000$ pairs is increasing (BirdLife International 2004), while the German population is stable (Table 4). A widespread occurrence in southern Sweden is to be expected according to SDM50 (Figure 2). Based on SDM50 and the population growth in Poland, we find it likely that the species will (re)establish in Sweden, despite the species' recent poor history in the country.

\section{Nightingale Luscinia megarhynchos}

The closest breeding populations of Nightingale are found in northern Germany and Poland (BirdLife International 2013). Just like the Thrush Nightingale Luscinia luscinia it breeds in lush scrub, but also in drier and more open shrub-dominated habi- 
tats (Cramp 1998). The SDM50 predicts a widespread occurrence in the southern parts of Sweden (Figure 2). The trends for individual countries vary, but the weighted European index is positive (Table 4). It is indicated by DOF (2013) to be on expansion in eastern Schleswig-Holstein and they predict a future occurrence in Denmark. Between 1982 and 2013, the Nightingale has increased in numbers also in the Czech Republic (CSO 2013).

\section{Cetti's Warbler Cettia cetti}

Cetti's Warbler, a non-migratory bird, is found in dense scrub. It has expanded northwards in Europe since the 1920s (Cramp 1998). The species has its closest populations in the UK and the Netherlands. The first breeding in Britain occurred in 1973 (Robinson et al. 2007) and today the population is estimated to about 2000 singing males (Baillie et al. 2013). Population growth in the UK and France seems to be largely controlled by the winter weather since this species is highly sensitive to cold winters (Robinson et al. 2007, Moussus 2010). All trend data for the Cetti's Warbler show an increase (Table 4). SDM50 predicts a limited presence in southern Sweden (Figure 2).

\section{Booted Warbler Iduna caligata}

The Booted Warbler appears in different types of scrubs (Cramp 1998, Shitikov et al. 2012). It has its main distribution in Russia and Kazakhstan, from where it has expanded to the west and northwest (del Hoyo et al. 2006). Shitikov et al. (2012) indicate that the expansion can be partly explained by the abandonment of agricultural land in parts of Russia. The first confirmed breeding in Finland was in 2000 (Valkama et al. 2011). The species continues to expand in Finland and the population was recently estimated to 10-50 pairs (Valkama et al. 2011). The Finnish distribution is concentrated to the southeast, especially in Karelia, but probable breeding attempts have been reported close to the Finnish west coast. The species was not modelled by Barbet-Massin et al. (2012) but by Jiguet \& Barbet-Massin (2013), who predicted an increase in range size and a western range shift.

\section{Melodious Warbler Hippolais polyglotta}

The Melodious Warbler breeds in deciduous forest habitats (Cramp 1998). The nearest present occurrences are found in south-western Germany and Belgium (Engler et al. 2013). Along much of its northern border it hybridizes with the Icterine Warbler Hippolais icterina. This hybrid zone is moving northwards in favour of the Melodious (Secondi et al. 2006, Engler et al. 2013), which is an obvious signal of a large scale range expansion. Trend data from Belgium and Germany show that the species is increasing in numbers in the northern part of its range (Table 4). SDM50 suggests a future presence in southern Sweden (Figure 2).

Short-toed Treecreeper Certhia brachydactyla Unlike its sister species the Treecreeper Certhia familiaris, the Short-toed Treecreeper occurs exclusively in deciduous forest (Cramp 1998). Its nearest occurrence is in north-eastern Zealand in Denmark, just across the narrow strait of Öresund (DOF 2013). Population trends across Europe show both growths and declines (Table 4). However, the species is increasing in Denmark, and it seems reasonable that future colonizers will originate from there. The population increase between 1990 and 2000 in Denmark is estimated at 30 $50 \%$ (DOF 2013). The species has bred in Sweden once, at one site (2006 in Skåne) in a hybrid pair with Treecreeper (Strid 2007). SDM50 predicts a widespread occurrence in southern Sweden (Fig. 2).

\section{Possible establishments 2010-2050}

\section{Little Bittern Ixobrychus minutus}

The Little Bittern occurs in large parts of central and southern Europe. The nearest populations are found in the Baltic countries and Poland (BirdLife International 2013). It occurs in various types of wetlands with surrounding shrub or rows of trees (Cramp 1998). SDM50 predicts a widespread occurrence in Sweden, which should be compared with the relatively contradictory trend data (Table 5). Wetlands International (2012) notes that population trends in most Western European countries are either stable or increasing, but declining in the rest of Europe. However, the underlying data is generally of low quality.

\section{Night Heron Nycticorax nycticorax}

Night Herons breed at the closest in the Netherlands and southern parts of Poland and Germany (BirdLife International 2013). It occurs in similar environments as the Little Bittern. Trend data show both population increases and decreases (Table 5). Wetlands International (2012) classifies the European population as generally increasing. SDM50 predicts a very limited presence in southern Sweden. 


\section{Purple Heron Ardea purpurea}

Purple Herons nest primarily in large wetlands with extensive reedbeds (Cramp 1998). They occur in large parts of southern and central Europe. The current northern boundary extends across the Netherlands, central Germany and Poland (BirdLife International 2013). Generally, population trends are positive in Western Europe, but declining in Europe overall (Wetlands International 2012 and Table 5). SDM50 predicts a limited presence in southern Sweden.

\section{Black Stork Ciconia nigra}

This species is found primarily in older forests with wetlands (Cramp 1998). The nearest area where the Black Stork breeds is in the Baltic countries and Poland (BirdLife International 2013). It nested regularly in Sweden during the 1800s, but ceased as a regular breeding bird in the first half of the 1900s. There are occasional records of breeding from the early 2000s (Swedish Species Information Centre 2011c). Wetlands International (2012) indicates that the western population is increasing, but the Eastern European is declining. The Estonian population is estimated to have halved from the late 1970 s to early 2000s (Lõhmus \& Sellis 2003). SDM50 predicts a relatively common occurrence in predominantly central Sweden.

\section{Spoonbill Platalea leucorodia}

This species occurs in shallow wetlands with muddy or sandy bottoms. It accepts both saline and freshwater habitats (Cramp 1998). Spoonbills nest as close as in Denmark, where the population has increased from 2 pairs in 1996 (Grell 1998) to 101 pairs in 2011 (DOF 2013). Between 1990 and 2006 the populations in the western Mediterranean and Western Europe have increased by $15 \%$ annually, while the Central and Eastern European occurrences show a moderate decline (Wetlands International 2012). The species is now seen annually in Sweden but normally only single individuals (Species Gateway/Bird 2013). SDM50 predicts no presence in Sweden.

\section{Short-toed eagle Circaetus gallicus}

The Short-toed Eagle has its closest and most northerly occurrence in the Baltics where it occurs sparsely. It occurs in large parts of Central and Eastern Europe, but is almost absent in Western Europe (Hagemeijer \& Blair 1997). In the northern part of its range it occurs in areas with a mosaic of forest and open land (Cramp 1998). Little is known about population trends, but the weighted Europe- an index suggests a rather stable population (Table 5). The species is currently expanding northwards in France. Single individuals are found every year in Sweden, especially in summer and autumn, indicating that the Baltic Sea should not pose any serious dispersal barrier. SDM50 predicts a limited presence in southeastern Sweden.

\section{Lesser Spotted Eagle Aquila pomarina}

This species occurs in Central and Eastern Europe, including the Baltic countries (Hagemeijer $\&$ Blair 1997). The species prefers forest habitats that are broken up by open land (Cramp 1998). In 1991-1997 the Estonian population was estimated to 480-600 pairs (Lõhmus \& Väli 2001). These authors believe that the population grew rapidly in the 10-20 years prior to the study. The explanation they put forward is that the species increasingly began to use human-influenced environments such as agricultural land in search of food. Little is known about the species' population dynamics, but there is no information that indicates dramatic changes (BirdLife International 2013). Single pairs recently bred in France and even Spain. The species occurs regularly in Sweden, in summer and autumn. SDM50 predicts a restricted population in east central Sweden.

\section{Little Owl Athene noctua}

The Little Owl prefers open land, and in the northern part of its range in nests in areas with agricultural land, often in farm houses (Cramp 1998). Its northernmost outpost is in Denmark, where the population is declining. Between 1970 and 2011 the breeding population has decreased from over 1000 pairs (Andersen et al. 2013) to 55 pairs (DOF 2013). During the last two centuries only occasional breeding records were confirmed in Sweden, the last in the late 1930s and early 1940s (SOF 2002). The trends for individual countries show either stable or declining populations, whereas the pan-European index indicates stability (Table 5). SDM50 predicts a widespread occurrence in the southern third of Sweden.

\section{Citrine Wagtail Motacilla citreola}

The Citrine Wagtail has its main distribution in Russia, but from there it has expanded westwards (Hagemeijer \& Blair 1997). The species now nests regularly, albeit in low numbers, in most of the Baltic Sea countries and it increases in numbers (BirdLife International 2004). Between 2003 and 2012, about 12-27 Citrine Wagtails were observed annually in Sweden (Species Gateway/Bird 2013). 
Since then, a first pure breeding was confirmed in Södermanland (south Central Sweden) in 2013, followed by another one in Uppland 2014 (Species Gateway/Bird 2014). In addition, several hybridizations with Yellow Wagtail Motacilla flava have been recorded (Species Gateway/Bird 2013).

\section{Conceivable establishments 2010-2050}

In this category we put ten species or subspecies that, for various reasons, we can imagine as future breeding birds of Sweden. In general the level of uncertainty is higher than for the two previous categories.

\section{Red-creasted Pochard Netta rufina}

The species has its nearest breeding distribution in Denmark, where the population in 2011 was estimated at eight pairs (DOF 2013). The European population, not including the eastern Mediterranean area, showed a positive growth between 1997 and 2007 (Wetlands International 2012). In 2012 a pair nested in Lake Tåkern, Östergötland, which was the first confirmed breeding in Sweden (Species Gateway/Bird 2013).

\section{Fulmar Fulmarus glacialis}

The nearest breeding occurrence of Fulmars is found in southern Norway. Within Norway the population trends varies, but stocks in southern (Vest-Agder) and southwestern Norway (Rogaland) show recent significant increases (SEAPOP 2014). Over the past 25 years, occasional nesting attempts occurred in Denmark (DOF 2013). The species appears to increase in several European countries, but not in the UK (BirdLife International 2004). On the Swedish west coast down to northern Skåne the species occurs fairly frequently mainly in autumn, but no observations indicating nesting have been reported (Species Gateway/Bird 2013).

\section{Gannet Morus bassanus}

The closest breeding sites to Sweden are in Norway and Germany (BirdLife International 2004). Population sizes are increasing in all Western European countries where it occurs (BirdLife International 2004). Given that the species now is frequenting Swedish waters, especially off the West Coast, during most of the year (Species Gateway/ Bird 2013), it is not unreasonable that there will be establishment trials in Sweden. The lack of obvious suitable nesting cliffs may be a limiting factor, but it should be noted that the species has established colonies also on small low islets with bare rocks (c.f. Barrett 2008), a habitat present on the Swedish west coast.

\section{Pallid Harrier Circus macrourus}

This species has its main distribution in Russia where it has declined relatively sharply (BirdLife International 2013). Despite this, several nests and nesting attempts were reported in Finland during the 2000s, where it is said to be increasing (Valkama et al. 2011). In Sweden, the annual numbers of observed Pallid Harriers during 2009-2012 varied been between 42 and 200. In 2011, in the border regions of Jämtland and Lapland (northwestern Central Sweden), a summer record of a juvenile suggested a successful nearby breeding.

\section{Little Crake Porzana parva}

The Little Crake occurs over much of Europe and breed regularly in all the countries around the Baltic Sea, apart from Sweden (Bird Life International 2004). The populations are said to decrease somewhat. The number of records in Sweden has varied between zero and 5 in 1998-2012 (with an average of 2.6; Species Gateway/Bird 2013).

\section{Black-winged Stilt Himantopus himantopus}

The Black-winged Stilt occurs over much of Europe and breeds at its closest in Poland and Germany (BirdLife International 2004). Occasional nest records have been made in Denmark (DOF 2013), the last in 2013 (DOFbasen 2014). The European population is considered stable (Wetlands International 2012).

\section{Marsh Sandpiper Tringa stagnatilis}

This species has an eastern distribution in Europe and the majority of the population breed in Russia. Marsh Sandpiper breeds in several countries around the Baltic Sea, but in small numbers (BirdLife International 2004). The number of records in Sweden increased from 1985 to the mid-2000s and then decreased slightly. Between 2008 and 2012, the number of annual records has varied between 15 and 26 (Species Gateway/Bird 2013). The first breeding in Sweden was recorded in 2000 and after that there have been a few more nesting attempts (Species Gateway/Bird 2013).

\section{Caspian Gull Larus cachinnans}

The Caspian Gull has a south-eastern distribution in Europe (BirdLife International 2013). The nearest breeding population, as far as we know, is in central Poland, where it is found in various types of inland waters. In Poland the first nesting sites 
were found in 1981 and it has since expanded considerably (Neubauer et al. 2006). Between 1997 and 2004 the annual population growth in Poland was estimated to $33 \%$ and in 2004 as many as 480 pairs bred (Neubauer et al. 2006). In 2007, 800 pairs breed in Poland (Gwiazda et al. 2011), and it is predicted that the population will continue to increase (Gwiazda et al. 2011). The number of records has increased significantly in Sweden in recent years. In 2012 as many as 1200 records were made in Sweden, ten of which were ringed in Poland (Species Gateway/Bird 2013). To what extent this increase is due to an actual increase in numbers or that the bird watchers learned to better identify the species, is unclear. There are no breeding records of this species in Sweden.

White-spotted Bluethroat Luscinia svecica cyanecula

White-spotted Bluethroats occur across Central and Western Europe, where it breeds in reedbeds, scrub areas and crop fields (Hagemeijer \& Blair 1997), a strikingly different habitat preference to that of the nominate subspecies, Luscinia s. svecica, which breeds in subalpine birch forests and alpine willow areas. The West European population of L. S. cyanecula is presently increasing in numbers (BirdLife International 2004). In 1992 the first breeding record of White-spotted Bluethroat in Denmark in about 100 years was recorded. In 2007 the Danish population was estimated at 105 pairs (DOF 2013). However, over the past decade this subspecies has not even been encountered yearly in Sweden (Species Gateway/Bird 2013).

\section{Lanceolated Warbler Locustella lanceolata}

The Lanceolated Warbler is another eastern warbler that has expanded westwards in Europe the last decades, from breeding grounds near the Ural Mountains (Hagemeijer \& Blair 1997). It has been predicted by Jiguet \& Barbet-Massin (2013) to start breeding in northernmost Sweden until year 2100 . There has been a slow increase in the numbers recorded in Finland, with 12 singing males in 2014 (Tarsiger 2014). In Sweden there are so far only four singing males recorded, but indeed, all have been found in the northern half of the country (Species Gateway/Bird 2013). There are no breeding records yet in either Sweden or Finland.

\section{Establishment of new species in 1850-2050}

Given that our estimates of future establishments are reasonably accurate, the rate of establishment will increase substantially. In 1850-1969, 2.3 new species per decade were established in Sweden, and from 1970 to 2009 , the figure was 2.5 species per decade. The forecast for 2013-2050 is 2.9 new species per decade (based on probable colonizers) or 5.3 (based on probable and possible colonizers). An increased immigration rate of new species into northern Europe can indeed be expected (BarbetMassin et al. 2012). However, the models used by Barbet-Massin et al. (2012) to create future distributions have their potential limitations. Obviously, the birds must be able to reach the new suitable areas. For example, montane and relatively sedentary birds of central Europe must cross vast stretches of lowland to reach the Scandinavian mountains.

Further, the expansion of a species into new areas may potentially lead to competition between species that have not co-existed before, something the models did not take into account. There are three potential scenarios: 1) stable coexistence (which the Barbet-Massin et al. models assume), 2) the colonizing species does not manage to establish itself, or 3) the colonizing species out-compete the established species. Accordingly, the future number of species in a given area may be overestimated.

\section{Extinctions 2010-2050}

We here choose a different approach compared to that used in the analysis of potential future species when presenting the results. Instead of categorizing species in different classes (for example, probably or possibly extinct in 2050), we treat a number of species individually. We first look at the SDM50 that predict extinction and then we discuss the species that today are most threatened in Sweden. Although history speaks against us, it is not obvious that any species will disappear from the Swedish breeding avifauna by 2050 . The reason is that conservation measures will be taken for many of the most threatened species. The taxa we consider most at risk of extinction are the Lesser Whitefronted Goose Anser erythropus, the Baltic Dunlin Calidris alpina schinzii, the White-backed Woodpecker Dendrocopos leucotos and the Tawny Pipit Anthus campestris.

\section{Extinctions according to SDM50}

According to the SDM50, eight species are threatened with extinction by the year 2050. However, we find it unlikely that any of them would be extinct in Sweden within the period. Of the eight spe- 
cies, five are closely tied to water (see Method for the problems associated with forecasts for these species): Great Cormorant Phalacrocorax carbo, Barnacle goose, Avocet Recurvirostra avosetta, Sandwich Tern Sterna sandvicensis and Little Tern Sternula albifrons. The first three species have expanded in Sweden during the last decades (Ottosson et al. 2012), as they have done over large parts of Europe (BirdLife International 2004), and we see no reason for the populations to collapse. The Avocet, for example, has since the mid-1940s increased its population in Western Europe fivefold (Hötker \& West 2005).

The latest estimate of the Swedish population of Sandwich Tern is 460 pairs (Ottosson et al. 2012). The European population is considered to be stable (BirdLife International 2013) and in the Netherlands, which holds a large proportion of the European population, there has been a moderate increase between 1990 and 2011 (Netwerk Ecologische Monitoring 2012). In contrast, the Sandwich Tern has decreased with more than $20 \%$ in Germany between 1980 and 2005 (Südbeck et al. 2007). In Sweden the population halved between 1975 and the late 1990s, but then stabilized at 400-500 pairs (Swedish Species Information Centre, 2011d). Overall, we estimate that the future of the Sandwich tern in Sweden is uncertain, but we believe it is quite unlikely that the species is extinct in Sweden in 2050.

The Little tern breeds with some 500 pairs in Sweden (Ottosson et al. 2012), and the population appears to have been stable since the early 1970s (see Swedish Species Information Centre 2011e). Although the European population as a whole declined slightly between 1970 and 2000, it seems as if the populations in countries close to Sweden, with the exception of Poland, are stable (BirdLife International 2004)

The other three species which according to the models are predicted to disappear are Bar-tailed Godwit Limosa lapponica, Collared Flycatcher Ficedula albicollis and Arctic Redpoll Carduelis hornemanni. In Sweden there are about 200 pairs of Bar-tailed godwit breeding. They nest in the willow zone of the montane tundra and the species has slowly increased in both distribution area and numbers (Ottosson et al. 2012). We find it unreasonable that the habitat which Bar-tailed Godwit is connected to would be missing in already 35 years. There is also no trend data that show a decrease in northern Europe. On the contrary, the population has increased by $1.4 \%$ annually between 1989 and 2007 (Wetlands International 2012).
The Collared Flycatcher Ficedula albicollis is another species that SDM50 predicts to disappear from Sweden, but this seems highly unlikely given the current situation. Collared Flycatcher has its main distribution in Central Europe. From Poland we have no population trend data, but in the Czech Republic it increases in numbers (CSO 2013). Also in the joint trend for Europe it is increasing (BirdLife International 2013). And last but not least, the species is currently expanding in Sweden. For a long time it only bred on Gotland, but it is now established also on Öland, where it is increasing in numbers (Ottosson et al. 2012). However, its African wintering distribution is predicted to become greatly reduced in the 21 st century as a result of climate change (Barbet-Massin et al. 2009).

The Arctic Redpoll is a rare breeder on montane tundra and in the upper mountain forest in northernmost Sweden. The population size and dynamics are poorly known, with an uncertain population estimate of some 3800 pairs (Ottosson et al. 2012). As far as known the populations in northern Fennoscandia and Arctic Russia remained stable between 1970 and 2000 (BirdLife International 2004). As in the case of Bar-tailed Godwit, we do not envision that the habitats utilized during the nesting season would be threatened already before 2050 .

\section{Critically Endangered species}

Not surprisingly, the species treated in this section are those who are already recognized as threatened in Sweden. The species discussed below comprise the six taxa that are categorized as Critically Endangered (CR) in the Swedish Red List (Gärdenfors 2010) and one species, Tawny Pipit Anthus campestris, which is classified as Endangered (EN).

Lesser White-fronted Goose Anser erythropus

The Swedish population was estimated at 15-25 pairs in 2010. In Fennoscandia there were another 15-20 pairs, all in northern Norway (County Administrative Board of Norrbotten 2011). Since then, the Swedish population has declined, and the current population is estimated to $8-12$ pairs $(\mathrm{N}$. Liljebäck, pers. comm). The Swedish population is derived largely from the reinforcements made in 1981-1999 (County Administrative Board of Norrbotten 2011), and subsequently in 2009-2014. It therefore seems likely that the species today would have been extinct if it was not for these active measures. The Lesser White-fronted Goose has declined dramatically in many parts of its range (BirdLife 
International 2013), which means that the Swedish population is considered an isolate. Considering this and the very low numbers, the species' future in the country is for the foreseeable future dependent on conservation measures.

\section{Baltic Dunlin Calidris alpina schinzii}

The Baltic dunlin, which was previously common in southern Sweden, has declined in numbers dramatically. Between 1990 and 2000, the Swedish population decreased by $33 \%$ and between 2000 and 2008 with a further 50-60\%. In 2008 the Swedish population was down to 100 pairs, with 61 pairs on Öland (Swedish Species Information Centre 2012b). It persists today only in grazed coastal meadows. A sensitivity analysis for the breeding population of Öland stock showed that it would most likely disappear within 24 years (Betzholtz et al. 2010). It has also been shown that the small populations that exist along the Swedish West Coast are threatened by genetic depletion (Blomqvist et al. 2010). The subspecies also decreases sharply in Germany (Südbeck et al. 2007) and Denmark (DOF 2013) and it is also in decline in Poland (Chodkiewicz et al. 2013). We believe there is a real risk that this subspecies will be extinct in Sweden before 2050.

\section{Black-tailed Godwit Limosa limosa}

Black-tailed Godwit numbers have fallen sharply in Sweden and in 2009 the Swedish population was estimated to 90 pairs, with 33 pairs on Öland (Swedish Species Information Centre, 2011f). During censuses on Öland in 2013, 53-55 pairs were found (R. Ottvall, personal communication). There is evidence that populations outside Öland have decline further since 2009 (R. Ottvall, personal communication). The species also decreases in Europe as a whole (Wetlands International 2012). The action plan developed by the EU to improve the situation of Black-tailed Godwit indicated habitat deterioration in breeding areas as the single most important factor for the European population decrease (European Commission 2007). Given that member states comply with the recommendations given by the European Commission (2007), there should be a future for the Black-tailed Godwit in Sweden.

\section{Barn Owl Tyto alba}

Ottosson et al. (2012) estimated the Swedish population to 10 pairs with most pairs on Gotland. It occurs in open cultural landscape where it nests in barns and similar buildings. Cold winters can re- duce the population significantly (Ottosson et al. 2012). The little stock in itself puts the species at high risk of extinction. What speaks against that the barn owl will disappear from Sweden is that the species at present is increasing in Denmark (DOF 2013), Germany (Südbeck et al 2007) and the Netherlands (Netwerk Ecologische Monitoring, 2012). The population rise in Denmark is explained by large amounts of nest boxes being offered in recent years (DOF 2013). Lack of nest sites is often given as an explanation for the species decline in some areas (Swedish Species Information Centre 2012c). Local groups of conservationists in southernmost Sweden now follow the Danes' example and put out nest boxes, but so far without any measurable results.

\section{Snowy Owl Bubo scandiacus}

The Snowy Owl has a circumpolar distribution. Its population density in a given area fluctuates with the occurrence of lemmings, which forms the species staple food during the breeding season (Cramp 1998). In Sweden it has been found breeding in single years since the early 1970 s, most recently in 2011 when three nests were documented. In 1978 several hundred pairs bred in the Västerbotten and Norrbotten mountains (Swedish Species Information Centre, 2012d). Climate change may pose a future threat. Gilg et al. (2009) showed that the forecasted future warmer summers in the arctic environment may make lemming peaks less pronounced, that they will occur less often and that they may even be terminated. The future status of the Snowy Owl in Sweden remains uncertain.

White-backed Woodpecker Dendrocopos leucotos This rare woodpecker has declined dramatically in numbers due to the decreasing number of old deciduous trees in the forests (Swedish Species Information Centre 2011g). The confirmed number of breeding pairs in Sweden was one in 2012 (Strid \& Eriksson 2013) and two in 2014 (M. Svensson pers. comm.), respectively. A species conservation project currently conducts active steps to recreate suitable habitat and release captive-bred individuals (Stighäll 2011). Without continued conservation measures there is an obvious risk that the species will very soon cease to exist as a breeding bird in Sweden.

\section{Tawny Pipit Anthus campestris}

The Tawny Pipit is linked to sandy heaths and coastal dune areas in Sweden. It has declined sharply in both Sweden and much of Western Eu- 
rope (BirdLife International 2004). The species' distribution in Sweden in recent years has been limited to Skåne and Halland (Ottosson et al. 2012). However, no breeding birds were found in Halland in 2012-2014, despite active search (Species Gateway/Bird 2014). In Skåne, the number of known territories declined from 210 to 42 between 1983 and 2008 (Bergendahl 2009). Overgrown coastal sand dunes have been identified as a reason for the sharp decline in Sweden. Restoration of such areas can certainly benefit the Tawny Pipit, but considering that the sharp decline in Sweden goes hand in hand with a greater geographic reduction, there is an obvious risk that the species will disappear from the Swedish fauna.

Of the seven taxa for which we believe there is a clear risk of extinction in Sweden until 2050, three are the subject of specific conservation measures, where captive breeding and assistance with nest sites is included. The future of these species is probably largely dependent on how enduring and successful these projects will be.

For the Lesser White-fronted Goose, Baltic Dunlin, White-backed Woodpecker and the Tawny Pipit the future in Sweden looks particularly uncertain.

\section{Establishment of species not naturally occurring in Europe - alien species}

The species discussed above all have their natural occurrence in Sweden or Europe. Below we discuss the potential establishment in Sweden of some escaped or introduced species established in Europe, which may begin to breed regularly in Sweden. We make no attempts to analyze the consequences of such establishments, but only present the species that may establish a breeding population in Sweden.

\section{Egyptian Goose Alopochen aegyptiaca}

This species originally breeds in Africa. The European population of Egyptian Goose originate from individuals that escaped from captivity. In Europe it has its stronghold in the UK, Belgium, Netherlands and Germany (BirdLife International, 2013). The breeding population in the UK is estimated at 1,100 pairs (Robinson 2005; updated December 2013), in Germany to between 2200 and 2600 pairs (Bauer and Woog, 2008) and in the Netherlands, where the first breeding was confirmed in 1967, to 10000 pairs (Gyimesi \& Lensink 2012). In Denmark the species bred at 7-8 sites in 2009 (DOF 2013). The total estimate for Western Europe is $>26000$ pairs (Gyimesi \& Lensink 2012). The rap- id population growth in the Netherlands probably depends on the ample supply of fresh water adjacent to grasslands, a preferred habitat combination (Gyimesi \& Lensink, 2012).

The first reported sighting of Egyptian Goose in Sweden is from 1999 (Species Gateway/Bird 2013). The first confirmed breeding was made in Skåne 2004. Subsequently, two additional breedings were confirmed (in 2006 and 2008; Species Gateway/Bird 2013). According to the same source, the numbers of spontaneous reports have decreased since the peak year of 2007. If this is due to a true reduction in birds present in Sweden or a reduced willingness to report the species is unclear. Sweden undoubtedly harbours suitable habitat to be colonized by Egyptian Goose. Whether this will happen depends on the actions performed in Sweden and Europe to prevent further expansion of the species. Notably, the exponential increase in the number of breeding pairs that have taken place in several countries after the species first was found nesting (Gyimesi \& Lensink, 2012) did not occur in Sweden.

\section{Mandarin Duck Aix galericulata}

Since the males have a very spectacular appearance, the species has long been a popular bird in parks. The species is considered to be established as a breeder in sex European countries (van Kleunen \& Lemaire 2014). The population in the UK, which is Europe's largest, was estimated in 1988 to 2300 pairs (Robinson 2005). According to NNSS (2014) it is likely that the population has increased since then. Also in Germany the species expands (Bauer \& Woog 2008).

Since the early 2000s there have been around 30-60 records of Mandarin Duck yearly in Sweden and nearly every year occasional breeding attempts have been reported (Species Gateway/Bird 2013). As far as we know there are no measures taken in Europe to prevent a further spread of the species, which at least partly can be explained by the notion that the ecological risks associated with the establishment of the species are low (Owen et al. 2006 ). Given that no action is taken against an establishment of Mandarin Duck in Sweden or elsewhere, it seems likely that the species will become established at least on a small scale. However, since the species has been found in low numbers in Sweden for at least 15 years without any significant increase reported, there will probably not be a dramatic expansion of this species. 


\section{Ruddy Duck Oxyura jamaicensis}

The Ruddy Duck breeds in several Western European countries, but only in larger numbers in the UK (Hagemeijer \& Blair 1997). The whole of the Western European population is probably derived from seven individuals who were brought to the UK in 1948 (Munoz-Fuentes et al. 2006). The Ruddy Duck is a major threat to the European sister species the White-headed Duck Oxyura leucocephala. Because of this threat, intensive campaigns to minimize the number of Ruddy Ducks in Europe are in action (Hughes et al. 2006).

The years of 2003 and 2004 were the peak year in terms of the number of observations in Sweden, when six and nine individuals were reported (Species Gateway/Bird 2013). In the early 2000s even a few nesting records were made. Between 2009 and 2012, no observations were reported (Species Gateway/Bird 2013). The efforts made in Europe to minimize the number of Ruddy Ducks have possibly influenced the situation in Sweden and it presently seems unlikely that the species will establish itself in Sweden.

\section{Rose-ringed Parakeet Psittacula krameri}

The European populations descend from escaped individuals. The species is now well established in several southern and western European countries, where it is mainly found in parks in urban environments, and it is expanding (DAISIE 2009). The nearest occurrences are found in Germany, the Netherlands and the UK. The number of records has increased in Denmark, and it is not unlikely that the species will become established in the Copenhagen area (DOF 2013).

During the 2000s, only a handful of records have been made in Sweden (Species Gateway/Bird 2013). We do not find it likely that the species will become established in Sweden in the foreseeable future, but if it does establish in Copenhagen, future establishment in Sweden cannot be excluded.

\section{Conclusion}

Following a slow and steady increase in the number of bird species since the last ice age (Ericson \& Tyrberg 2004), the number of species in the Swedish avifauna has increased continuously also from 1850 until today. During this period many species have been lost, but the number of new species established was three times as many. In addition, the rate of turnover has been rather constant during the 160 years considered, which is remarkable given the powerful changes occurring in the environment during all these years.
A significant part of this report aims at forecasting the future bird species establishments and extinctions in Sweden. We have strived to make this as objectively as possible, based on habitat and climate-based models and recent information from surrounding countries. We categorized the potential newcomers into three categories: probable, possible and conceivable. The placement of a species in a given group can of course be discussed. But the overall picture is not altered by that, or by different conclusions about some threatened species. Also in coming decades, the number of establishments will most likely exceed the number of extinctions. As mentioned earlier, there are indeed reasons to assume that the number of species in Sweden will increase at an accelerating rate due to global warming (Thuiller et al. 2005, Barbet-Massin et al. 2012).

\section{Acknowledgements}

We are most grateful to Mats OG Eriksson, Mikael Svensson and Staffan Ulfstrand for comments on a previous version of the MS, and to the Swedish Environmental Protection Agency for financial support.

\section{References}

Andersen, L. H., Pertoldi, C., Loeschcke, V., Laursen, J. T., Jensen, T. H., \& Kristensen, T. N. 2013. Kan kirkeuglen Athene noctua reddes i Danmark? Flora og Fauna, 119(1+2): 1-9.

Asbirk, S., Berg, L., Hardeng, G., Koskimies, P. \& Petersen, A. 1997. Population sizes and trends of birds in the Nordic Countries: 1978-1994. Nordic Council of Ministers, Copenhagen.

Baillie, S. R., Marchant, J. H., Leech, D. I., Massimino, D., Eglington, S. M., Johnston, A., Noble, D. G., Barimore, C., Kew, A. J., Downie, I. S., Risely, K. \& Robinson, R. A. 2013. BirdTrends 2012: trends in numbers, breeding success and survival for UK breeding birds. BTO Research Report No. 644

Barbet-Massin, M., Thuiller, W. \& Jiguet, F. 2012. The fate of European breeding birds under climate, land-use and dispersal scenarios. Glob. Chang. Biol. 18: 881-890.

Barbet-Massin, M., Walther, B., Thuiller, W., Rahbeck, C. \& Jiguet, F. 2009. Potential impacts of climate change on the winter distribution of Afro-Palaearctic migrant passerines. Biology Lett. 5: 248-251.

Barrett, R. T. 2008. Recent establishments and extinctions of Northern Gannet Morus bassanus in North Norway, 1995-2008. Ornis Norvegica 31: 172-182.

Bauer, H.-G. \& Woog, F. 2008. Non-native and naturalized bird species (neozoa) in Germany, part I: occurrence, population size and status. Vogelwarte 46: 157-194.

Bengtsson, K. \& Green, M. 2013. Skånes Fågelatlas. Skånes Ornitologiska Förening, Vellinge. 
Bergendahl, R. 2009. Fältpiplärka (Anthus campestris) $i$ Skåne 2008. Länsstyrelserapport: 2009:18, Länsstyrelsen i Skåne län.

Betzholtz, P., Berger, T., Petersson, J. \& Stedt, J. 2010. What do population viability analyses tell about the future for Baltic Dunlin Calidris alpina schinzii and Montagu's Harrier Circus pygargus on Öland? Ornis Svecica 20: 93-102.

BirdLife International 2004. Birds in Europe: population estimates, trends and conservation status. BirdLife International, Cambridge, UK.

BirdLife International. 2013. IUCN Red List for birds. http:// www.birdlife.org.

Blomqvist, D., Pauliny, A., Larsson, M. \& Flodin, L.-A. 2010. Trapped in the extinction vortex? Strong genetic effects in a declining vertebrate population. BMC Evol. Biol. 10: 1-9.

BWPi 2006. Birds of the Western Palearctic Interactive. BirdGuides, Oxford University Press.

Cederroth, C. 1996. Sällsynta fåglar i Sverige 1995. In Fågelåret 1996 (Bentz, P.-G. \& Wirdheim, A. eds). Vår Fågelvärld, suppl. 25.

Chodkiewicz, T., Neubauer, G., Chylarecki, P., Sikora, A., Cenian, Z., Ostasiewicz, M., Wylegała, P., Ławicki, Ł., Smyk, B., Betleja, J., Gaszewski, K., Górski, A., Grygoruk, G., Kajtoch, Ł., Kata, K., Krogulec, J., Lenkiewicz, W., Marczakiewicz, P., Nowak, D., Pietrasz, K., Rohde, Z., Rubacha, S., Stachyra, P., Świętochowski, P., Tumiel, T., Urban, M., Wieloch, M., Woźniak, B., Zielińska, M. \& Zieliński, P. 2013. Monitoring Ptaków Polski w latach 2012-2013. Biuletyn Monitoringu Przyrody 11: 6-73.

Colmant, L. 2006. Evolution récente de la population du pic mar Dendrocopos medius dans la région de chimay (Belgique). Alauda 74: 353-364

County Administrative Board of Norrbotten 2011. Åtgärdsprogram för fjällgås (Anser erythropus) 20112015. Rapport 6434, Naturvårdsverket, Stockholm.

Cramp, S. 1998. The Complete Birds of the Western Palearctic on CD-ROM. Oxford University Press, Oxford.

CSO. 2013. Population trends of birds in the Czech Republic. Czech Society for Ornithology. http://jpsp.birds.cz/ vysledky.php?menu=indices trends

DAISIE 2009. Handbook of Alien Species in Europe. Springer Verlag, Dordrecht.

Davey, C. M., Devictor, V., Jonzén, N., Lindström, A. \& Smith, H. G. 2013. Impact of climate change on communities: revealing species' contribution. J. Anim. Ecol. 82: $551-561$

del Hoyo, J., Elliott, A. \& Sargatal, J. 2006. Handbook of the birds of the world, vol. 11. Lynx Edicions, Barcelona, Spain.

DOF. 2013. Danmarks fugle. Dansk Ornitologisk Forening. http://www.dofbasen.dk/ART/

DOFbasen. 2014. Dansk Ornitologisk Forenings database over observationer af fugle. http://www.dofbasen.dk/

Engler, J. O., Rödder, D., Elle, O., Hochkirch, A. \& Secondi, J. 2013. Species distribution models contribute to determine the effect of climate and interspecific interactions in moving hybrid zones. J. Evol. Biol. 26: 2487-2496.

Ericson, P.G.P. \& Tyrberg, T. 2004. The early history of the Swedish avifauna. A review of the subfossil record and early written sources. Kungl. Vitterhets Historie och Antikvitets Akademiens Handlingar, Antikvariska serien, 45.

European Commission 2007. Management Plan for Black- tailed Godwit (Limosa limosa) 2007-2009. European Communities, Luxembourg.

Gilg, O., Sittler, B. \& Hanski, I. 2009. Climate change and cyclic predator-prey population dynamics in the high $\mathrm{Ar}$ ctic. Glob. Chang. Biol. 15: 2634-2652.

Gwiazda, R., Bukacinski, D., Neubauer, G., Faber, M., Betleja, J., Zagalska-Neubauer, M., Bukacinska, M. \& Chylarecki, P. 2011. Diet composition of the Caspian Gull (Larus cachinnans) in inland Poland: effects of breeding area, breeding stage and sympatric breeding with the Herring Gull (Larus argentatus). Ornis Fennica 88: 80-89.

Gyimesi, A. \& Lensink, R. 2012. Egyptian Goose Alopochen aegyptiaca: an introduced species spreading in and from the Netherlands. Wildfowl 62: 126-143.

Gärdenfors, U. (ed.) 2010. Rödlistade arter i Sverige 2010 - The 2010 Red List of Swedish Species. Swedish Species Information Centre, SLU, Uppsala.

Hagemeijer, E. J. M. \& Blair, M. J. 1997. The EBCC Atlas of European Breeding Birds: their distribution and abundance. T \& A.D. Poyser, London.

Holmbring, J.-Å. \& Pettersson, B. 1983. Mellanspetten utdöd i Sverige. Vår Fågelvärld 42: 454-458.

Hughes, B., Robinson, J. A., Green, A. J., Li, Z. W. D. \& Mundkur, T. 2006. International Single Species Action Plan for the Conservation of the White-headed Duck (Oxyura leucocephala). CMS Technical Series No. 13 \& AEWA Technical Series No.8, Bonn, Germany,.

Huntley, B., Green, R. E., Collingham, Y. C. \& Willis, S. G. 2007. A climatic atlas of European breeding birds. Lynx Edicions, Barcelona.

Hötker, H. \& West, R. 2005. Population size, population development and habitat use by Avocets in Western Europe at the end of the 20th century. Wader Study Group Bulletin 107: $57-65$.

IPCC. 2007. Climate Change 2007: Synthesis Report. Cambridge University Press, Cambridge, UK.

Jiguet F, Barbet-Massin M. 2013. Climate change and rates of vagrancy of Siberian bird species to Europe. Ibis 155: 194-198.

Jiguet, F., Barbet-Massin, M., Devictor, V., Jonzén, N. \& Lindström, A. 2013. Current population trends mirror forecasted changes in climatic suitability for Swedish breeding birds. Bird Study 60: 60-66.

Jiguet, F., Devictor, V., Ottvall, R., Van Turnhout, C., Van der Jeugd, H. \& Lindström, A.. 2010. Bird population trends are linearly affected by climate change along species thermal ranges. P. R. Soc. B. 277: 3601-3608.

JNCC. 2013. Seabird Population Trends and Causes of Change: 1986-2012 Report. Joint Nature Conservation Committee. http://www.jncc.defra.gov.uk/page-3201

Järvinen, O. \& Ulfstrand, S. 1980. Species turnover of a continental bird fauna: Northern Europe, 1850-1970. Oecologia 46: 186-195.

Kosiński, Z. \& Winiecki, A. 2005. Factors affecting the density of the middle spotted woodpecker Dendrocopos medius: a macrohabitat approach. J. Ornithol. 146: 263-270.

Ławicki, Ł. 2014. The Great White Egret in Europe: population increase and range expansion since 1980. Brit. Birds 107: 8-25.

Le Viol, I., Jiguet, F., Brotons, L., Herrando, S., Lindström, Å., Pearce-Higgins, J. W., Reif, J., Van Turnhout, C. \& Devictor, V. 2012. More and more generalists: two decades of changes in the European avifauna. Biology Lett. 8: 780-782. 
Lindström, Å. \& Green, M. 2013. Övervakning av fåglarnas populationsutveckling. Årsrapport för 2012. Rapport, Biologiska institutionen, Lunds Universitet

Lindström, Å., Green, M., Paulson, G., Smith, H. G. \& Devictor, V. 2013. Rapid changes in bird community composition at multiple temporal and spatial scales in response to recent climate change. Ecography 36: 313-322.

Lõhmus, A. \& Sellis, U. 2003. Nest trees - a limiting factor for the black stork population in Estonia. Aves 40: 84-91.

Lõhmus, A. \& Väli, Ü. 2001. Numbers and population dynamics of the Lesser Spotted Eagle Aquila pomarina in Estonia. Acta Ornithoecologica 4: 291-295.

MNP 2006. Integrated modelling of global environmental change. In An Overview of IMAGE 2.4 (Bouwman, A. F., Kram, T. \& Klein Goldewijk, K. eds.). Netherlands Environmental Assesment Agency (MNP), Bilthoven, The Netherlands.

Moussus, J.-P. 2010. Influences du climat sur la démographie des passereaux communs. Thèse de Doctorat de l'Université Pierre et Marie Curie. UPMC, Paris, France.

Munoz-Fuentes, V., Green, A. J., Sorenson, M. D., Negro, J. J. \& Vila, C. 2006. The ruddy duck Oxyura jamaicensis in Europe: natural colonization or human introduction? Mol. Ecol. 15: 1441-1453.

Müller, J., Pöllath, J., Moshammer, R. \& Schröder, B. 2009. Predicting the occurrence of Middle Spotted Woodpecker Dendrocopos medius on a regional scale, using forest inventory data. Forest Ecol. Manag. 257: 502-509.

Netwerk Ecologische Monitoring. 2012. Sovon Vogelonderzoek Nederland \& CBS. http://www.sovon.nl

Neubauer, G., Zagalska-Neubauer, M., Gwiazda, R., Faber, M., Bukaciński, D., Betleja, J. \& Chylarecki, P. 2006. Breeding large gulls in Poland: distribution, numbers, trends and hybridisation. Vogelwelt 127: 11-22.

NNSS. 2014. GB non-native species secretariat. http://www. nonnativespecies.org/home/index.cfm

Ottosson, U., Ottvall, R., Green, M., Gustafsson, R., Haas, F., Holmqvist, N., Lindström, Å., Nilsson, L., Svensson, M., Svensson, S. \& Tjernberg, M. 2012. Fåglarna $i$ Sverige: antal och förekomst. Sveriges Ornitologiska Förening, Halmstad.

Ottvall, R., Edenius, L., Elmberg, J., Engström, H., Green, M., Holmqvist, N., Lindström, Å., Tjernberg, M. \& Pärt, T. 2009. Population trends for Swedish breeding birds. Ornis Svecica 19: 117-192.

Owen, M., Callaghan, D. \& Kirby, J. 2006. Guidelines on Avoidance of Introductions of Non-native Waterbird Species. AEWA Technical Series No.12, Bonn, Germany.

Paquet, J.-Y., Jacob, J.-P., Kinet, T. \& Vansteenwegen, C. 2010. Les tendances des populations d'oiseaux communs en Wall onie de 1990 à 2009. Aves 47: 1-19.

Pettersson B. 1985. Extinction of an isolated population of the Middle Spotted Woodpecker Dendrocopos medius (L.) in Sweden and its relation to general theories on extinction. Biol. Conserv. 32: 335-353.

Pigot, A. L., Owens, I. P. F. \& Orme, C. D. L. 2010. The environmental limits to geographic range expansion in birds. Ecol. Lett. 13: 705-715.

Robinson, R. A. 2005. BirdFacts: profiles of birds occurring in Britain \& Ireland,BTO Research Report 407. BTO, Thetford. http://www.bto.org/birdfacts

Robinson, R. A., Freeman, S. N., Balmer, D. E. \& Grantham, M. J. 2007. Cetti's Warbler Cettia cetti: analysis of an expanding population: Capsule Productivity in the UK Cetti's Warbler population is constant, but overwinter survival has become increasingly dependent on winter temperatures. Bird Study 54: 230-235.

Romdal, T. S., Denesen, L. \& Grell, M. B. 2013. Udviklingen i antallet af ynglende fuglearter i Danmark 1800-2012. Dansk Ornitologisk Forenings Tidsskrift 107: 281-290.

SEAPOP. 2014. Seabird populations. http:/www.seapop.no/ Secondi, J., Faivre, B. \& Bensch, S. 2006. Spreading introgression in the wake of a moving contact zone. Mol. Ecol. 15: 2463-2475.

Shitikov, D. A., Fedotova, S. E. \& Gagieva, V. A. 2012. Nest Survival, Predators and Breeding Performance of Booted Warblers Iduna caligata in the Abandoned Fields of the North of European Russia. Acta Ornithol. 47: 137-146.

SOF 2002. Sveriges fåglar, 3:e upplagan. Sveriges Ornitologiska Förening, Stockholm.

Solonen, T. 1994. Structure and dynamics of the Finnish avifauna. Memoranda Soc. Fauna Flora Fennica 70: 1-22.

Species Gateway/Bird. 2013. Rapportsystem för fåglar [Online]. Swedish Species Information Centre, SLUs. Available at: http://artportalen.se/birds/ [Hämtad septembernovember 2013].

Species Gateway/Bird 2014. Rapportsystem för fåglar . Swedish Species Information Centre, SLU, Uppsala. http://artportalen.se/birds/

Stighäll, K. 2011. Vitryggig hackspett $i$ Sverige - hot och möjligheter, idag och i framtiden. Naturskyddsföreningen, Stockholm.

Strid, T. 2007. Fågelrapport 2006. In Fågelåret 2006 (Bentz, P.-G. \& Wirdheim, A., eds). Vår Fågelvärld, suppl. 47.

Strid, T. \& Eriksson, A. 2013. Fågelrapport 2012. In Fågelåret 2012 (Wirdheim, A. \& Bentz, P.-G. eds). Vår Fågelvärld, suppl. 53.

Swedish Species Information Centre. 2011a. Artfaktablad - Svartbent strandpipare Charadrius alexandrinus [Online]. Swedish Species Information Centre, SLU, Uppsala. http://www.artfakta.se/Artfaktablad/Charadrius_Alexandrinus_100027.pdf

Swedish Species Information Centre. 2011b. Artfaktablad - Härfågel Upupa epops. Swedish Species Information Centre, SLU, Uppsala. http://www.artfakta.se/Artfaktablad/Upupa_Epops_100143.pdf

Swedish Species Information Centre. 2011c. Artfaktablad Svart stork Ciconia nigra. Swedish Species Information Centre, SLU, Uppsala. http://www.artfakta.se/Artfaktablad/Ciconia Nigra 100032.pdf

Swedish Species Information Centre. 2011d. Artfaktablad - Kentsk tärna Sterna sandvicensis. Swedish Species Information Centre, SLU, Uppsala. http://www.artfakta.se/ Artfaktablad/Sterna_Sandvicensis_100135.pdf

Swedish Species Information Centre. 2011e. Artfaktablad Småtärna Sterna albifrons. Swedish Species Information Centre, SLU, Uppsala. http://www.artfakta.se/Artfaktablad/Sternula Albifrons 100133.pdf.

Swedish Species Information Centre. 2011f. Artfaktablad - Rödspov Limosa limosa. Swedish Species Information Centre, SLU, Uppsala. http://www.artfakta.se/Artfaktablad/Limosa_Limosa_100076.pdf

Swedish Species Information Centre. 2011g. Artfaktablad Vitryggig hackspett Dendrocopos leucotos. Swedish Species Information Centre, SLU, Uppsala. http://www.artfakta.se/Artfaktablad/Dendrocopos_Leucotos_100046.pdf 
Swedish Species Information Centre. 2012a. Artfaktablad Tofslärka Galerida cristata. Swedish Species Information Centre, SLU, Uppsala. http://www.artfakta.se/Artfaktablad/Galerida_Cristata_100060.pdf

Swedish Species Information Centre. 2012b. Artfaktablad Sydlig kärrsnäppa Calidris alpina schinzii. Swedish Species Information Centre, SLU, Uppsala. http://www.artfakta.se/Artfaktablad/Calidris_Alpina_Schinzii_100023.pdf

Swedish Species Information Centre. 2012c. Artfaktablad Tornuggla Tyto alba. Swedish Species Information Centre, SLU, Uppsala. http://www.artfakta.se/Artfaktablad/ Tyto_Alba_100142.pdf.

Swedish Species Information Centre. 2012d. Artfaktablad - Fjälluggla Bubo scandiacus. Swedish Species Information Centre, SLU, Uppsala. http://www.artfakta.se/Artfaktablad/Bubo_Scandiacus_100093.pdf

Swenson, N. G. 2008 . The past and future influence of geographic information systems on hybrid zone, phylogeographic and speciation research. J. Evol. Biol. 21: 421-434.

Südbeck, P., Bauer, H.-G., Boschert, M., Boye, P. \& Knief, W. 2007. The Red List of breeding birds of Germany, 4th edition. Ber. Vogelschutz 44: 23-81.

Tarsiger 2014. http://www.tarsiger.com

Thomas, C. D. \& Lennon, J. J. 1999. Birds extend their ranges northwards. Nature 399: 213-213.

Thuiller, W., Lavorel, S., Araújo, M. B., Sykes, M. T. \& Prentice, I. C. 2005. Climate change threats to plant diversity in Europe. Proc. Natl. Acad. Sci. U.S.A. 102: 8245-8250.

Valkama, J., Vepsäläinen, V. \& Lehikoinen, A. 2011. The Third Finnish Breeding Bird Atlas. Finnish Museum of Natural History and Ministry of Environment. http://atlas3.lintuatlas.fi/english

van Kleunen A. \& Lemaire A.J.J. 2014. A risk assessment of Mandarin Duck Aix galericulata in the Netherlands. Sovon-report 2014/15. Sovon Dutch Centre for Field Ornithology, Nijmegen.

Vermeersch, G. \& Anselin, A. 2009. Broedvogels in Vlaanderen in 2006-2007. Recente status en trends van Bijzondere Broedvogels en soorten van de Vlaamse Rode Lijst en/of Bijlage I van de Europese Vogelrichtlijn. Mededelin van het Instituut voor Natuur- en Bosonderzoek nr. 3, Brussel.

Wetlands International 2012. Report on the Conservation Status of Migratory Waterbirds in the Agreement Area, 5 th edition. Wetlands International, Wageningen, The Netherlands.

\section{Sammanfattning}

Utarmningen av arter på jorden, både globalt och regionalt är en stor fråga inom naturvården. Vi presenterar här vilka fågelarter och fågelraser som mellan 1850 och 2009 antingen nyetablerat sig i den svenska häckfågelfaunan eller upphört att vara svenska häckfåglar. Dessutom försöker vi förutsäga framtida etableringar och utdöenden fram till år 2050 .

Vår analys av nytillkomna och utdöda arter är gjord för två tidsperioder. För perioden 1850-1970 förlitar vi oss helt på den analys som gjordes av Järvinen \& Ulfstrand (1980). För perioden 1970 2009 har vi sammanställt information från olika svenska fågelfaunistiska källor, inte minst Ottosson et al. (2012).

Vad gäller förutsägelserna för tiden fram till 2050 grundar vi oss på resultat från olika modeller (s.k. Ecological Niche Models eller Species Distribution Models). Dessa modeller bygger på att man utefter en arts miljö- och klimatkrav idag försöker förutsäga var artens utbredningsområde kommer att ligga i framtiden, givet att klimatet och miljön förändras $i$ en viss riktning. De modellvärden vi har för Sverige kommer från studien av BarbetMassin et al. (2012). I korthet kan deras metod beskrivas enligt följande: med utgångspunkt från ett ornitologiskt uppslagsverk (BWPi 2006) digitaliserades och koordinatsattes utbredningsområdena för 409 i Europa häckande fågelarter (havsfåglar exkluderade). Upplösningen var på $0,5^{\circ}$ longitud och latitud $\left(0,5^{\circ}\right.$ latitud motsvarar ungefär $\left.55 \mathrm{~km}\right)$. Åtta variabler (även här med upplösningen $0,5^{\circ}$ ) som beskriver det nutida klimatet hämtades från Climate Research Unit (http://www.cru.uea.ac.uk/ data). Habitatuppgifter (nio habitatstyper, upplösning $0,5^{\circ}$ ), såväl nutida som framtida (år 2050), kom från IMAGE 2.4 modellen (MNP 2006). Författarna modellerade själva det framtida klimatet. Detaljer om detta finns i ursprungspublikationen (Barbet-Massin m.fl., 2012).

Utöver modellresultaten använde vi också aktuell information från våra grannländer om arter som minskar eller ökar i antal och utbredning (Tabell 1). Informationen från de båda källorna sammanvägdes när vi slutligen uppskattade de enskilda arternas sannolikhet för etablering eller utdöende i Sverige.

Mellan 1850 och 1969 etablerade det sig 28 arter/raser i Sverige (Järvinen \& Ulfstrand, 1980), medan det försvann nio arter. Detta kan jämföras med de tio arter/raser som tillkom och de tre arter som dog ut under den efterkommande perioden 1970-2009 (Figur 1, Tabell 2). Det innebär att etableringstakten var 2,3 (1850-1969) respektive 2,5 (1970-2009) arter/raser per decennium. Utdöendetakten, 0,75 arter/raser per decennium, var identisk de två perioderna emellan (Figur 1, Tabell 3). Generellt överstiger alltså antalet nyetablerade fågelarter i Sverige trefalt antalet utdöda arter under perioden 1850-2009. Vi fann inga uppenbara mönster med avseende på invandringsvägar och habitatspreferenser hos de arter som etablerade sig mellan 1970 och 2009.

Framtidsscenariot sträcker sig fram till år 2050. 
Fram till dess anser vi det troligt att elva nya arter/raser etablerar sig (Figur 2, Tabell 4). Dessa arter är silkeshäger, ägretthäger, svarthuvad mås, biätare, härfågel, mellanspett, sydnäktergal, cettisångare, stäppsångare, polyglottsångare och trädgårdsträdkrypare. För ytterligare nio arter/raser anser vi det troligt att de etablerar sig (Figur 2, Tabell 5). Dessa arter är dvärgrördrom, natthäger, purpurhäger, svart stork, skedstork, ormörn, mindre skrikörn, minervauggla och citronärla. Beaktas endast de troligt tillkommande arterna innebär det en framtida etableringstakt på 2,9 arter per decennium. Inkluderas även gruppen av möjligt tillkommande arter hamnar etableringstakten på 5,2 arter per decennium. Om vår prognos ligger hyggligt rätt kommer etableringstakten således att öka under de nästkommande decennierna. Det skulle i så fall vara i linje med andra, mer geografiskt storskaliga analyser som bland annat predikterar att den globala uppvärmningen kommer att resultera i ökad invandring av arter till nordliga områden (Huntley et al. 2007, Barbet-Massin et al. 2012).
De totalt sju arter/raser som enligt oss riskerar att dö ut innan år 2050 är samtliga sådana som idag klassificeras som akut eller starkt hotade på rödlistan. Arterna/raserna är fjällgås, sydlig kärrsnäppa, rödspov, tornuggla, fjälluggla, vitryggig hackspett och fältpiplärka. Flera av arterna ingår i åtgärdsprogram och framtiden för dessa arter är till stor del beroende av hur framgångsrika bevarandeåtgärderna är.

Vi analyserar också sannolikheten för invandring av fyra främmande arter, som från ett svensk perspektiv är relevanta att belysa, nämligen nilgås, mandarinand, amerikansk kopparand och halsbandsparakit. Av dessa är det endast nilgåsen som vi anser ha potential att etablera sig i nämnvärda numerärer.

Våra prognoser är självfallet behäftade med stor osäkerhet. Trots detta känner vi oss övertygade om att mönstret från 1850-2009 kommer att upprepas under de närmaste decennierna, det vill säga att antalet nyetablerade arter klart kommer att överstiga antalet utdöenden. 